\title{
The Risk Reduction Benefits of the Mesoamerican Reef in Mexico
}

\author{
Borja G. Reguero ${ }^{1 *}$, Fernando Secaira ${ }^{2}$, Alexandra Toimil ${ }^{3}$, Mireille Escudero ${ }^{4}$, \\ Pedro Díaz-Simal ${ }^{3}$, Michael W. Beck ${ }^{1,2}$, Rodolfo Silva ${ }^{4}$, Curt Storlazzi ${ }^{5}$ and \\ Iñigo J. Losada ${ }^{3}$
}

\begin{abstract}
${ }^{1}$ Institute of Marine Sciences, University of California, Santa Cruz, Santa Cruz, CA, United States, ${ }^{2}$ The Nature Conservancy, Mérida, Mexico, ${ }^{3}$ Environmental Hydraulics Institute "IHCantabria", Universidad de Cantabria, Santander, Spain, ${ }^{4}$ Instituto de Ingeniería, Universidad Nacional Autónoma de México, Mexico City, Mexico, ${ }^{5}$ United States Geological Survey, Pacific Center, Santa Cruz, CA, United States
\end{abstract}

\section{OPEN ACCESS}

Edited by:

Christophe Viavattene, Middlesex University, United Kingdom

Reviewed by:

Hyoungsu Park,

Oregon State University, United States

Elizabeth Christie,

University of Cambridge,

United Kingdom

*Correspondence:

Borja G. Reguero

breguero@ucsc.edu

Specialty section:

This article was submitted to Geohazards and Georisks,

a section of the journal

Frontiers in Earth Science

Received: 19 February 2019

Accepted: 09 May 2019

Published: 28 May 2019

Citation:

Reguero BG, Secaira F, Toimil A, Escudero M, Díaz-Simal P, Beck MW

Silva R, Storlazzi C and Losada IJ (2019) The Risk Reduction Benefits of the Mesoamerican Reef in Mexico.

Front. Earth Sci. 7:125.

doi: 10.3389/feart.2019.00125
Coastal development and climate change are dramatically increasing the risks of flooding, erosion, and extreme weather events. Coral reefs and other coastal ecosystems act as natural defenses against coastal hazards, but their degradation increases risk to people and property. Environmental degradation, however, has rarely been quantified as a driver of coastal risk. In Quintana Roo, Mexico, a region on the Mexican Caribbean coast with an annual tourism economy of 10 billion USD, coral reefs constitute a natural barrier against flooding from hurricanes. This study spatially quantifies the risk reduction benefits of the Mesoamerican Reef in Quintana Roo for people, buildings, and hotel infrastructure. The risk reduction benefits are substantial. For example, the reefs prevented $43 \%$ additional damage during Hurricane Dean in (2007) and provide nowadays hazard risk reduction for $4.3 \%$ of the people, $1.9 \%$ of the built capital, and $2.4 \%$ of the hotel infrastructure, per year. The annual benefits are estimated in 4,600 people, 42 million USD damage prevention for buildings, and 20.8 million USD for hotel infrastructure. The study also compares the risk reduction of coral reefs with (i) the protection offered by dunes and (ii) the increase in coastal risk from sealevel rise (SLR). The risk reduction of dunes is more critical where there are no coral reefs offshore and for small return-periods storms. Sea-level rise, however, will make the more frequent storms more impactful and will drive significant increases in annual expected damages across the region. However, we demonstrate that, in coral reef environments, the contribution of reef degradation to coastal risk is larger than the expected increase in risk from SLR. However, the spatial distribution of the risk reduction benefits from reefs differs for people and infrastructure, and in particular for hotels, which receive the most protection from reefs. Furthermore, many sections present larger benefits than the typical costs of restoration. This valuation makes a compelling case for protecting and maintaining this natural infrastructure for its risk reduction service, but also allows the development of piloting innovative strategies, such as risk finance and insurance strategies, that can align environmental and risk management goals.

Keywords: coastal risk, coral reefs, flood risk, environmental degradation, sea-level rise, losses and damages 


\section{INTRODUCTION}

People and assets in the coastal zones are increasingly exposed to the impact of hazards such as flooding and erosion. The combined effect of demographic concentration in low-elevation coastal zones (Silva et al., 2014; Neumann et al., 2015; Reguero et al., 2015) and the added threats of climate change such as sea-level rise (SLR) (Church et al., 2013) or increasing wave action from a more powerful global wave climate (Reguero et al., 2019) are ever putting coastal areas at an increasing risk. Climate change is a risk multiplier to coastal communities and economies (Hallegatte et al., 2013; Wong et al., 2014; Storlazzi et al., 2018). Addressing current and future coastal risk requires urgent action to mitigate the impacts from coastal hazards and increase the resilience of coastal communities.

Comprehensive risk management involves assessing risk and identifying ways to manage it (i.e., risk avoidance, risk transfer, risk reduction or risk retention). Such approaches aim at building long-term resilience in relation to extreme and slow onset events (UNFCCC, 2013). The Paris Agreement (article 8) reaffirmed the Warsaw International Mechanism for Loss and Damage as the main vehicle to avert, minimize and address loss and damage associated with climate change impacts, including extreme weather events and slow onset events (UNFCCC, 2015). Therefore, comprehensive risk management strategies need to be informed by the attribution of losses and damages to the different drivers of risk so that they can be better linked to strategies and actions and insurance and risk transfer (Briggs et al., 2015; Mechler and Schinko, 2016). However, research has been very limited on how the threats to coastal ecosystems can be linked with the risk of SLR and damaging storms on people and infrastructure. Furthermore, existing approaches currently largely overlook drivers of risk such as environmental degradation, whose contribution to risk, from a loss and damage perspective, is currently unapprised.

It is increasingly recognized that coastal ecosystems represent a natural infrastructure that provides coastal protection. However, their degradation is rarely appraised as an important driver of coastal risk to people and property. Coral reefs, for example, serve as natural, highly efficient submerged breakwaters that provide flood reduction benefits through wave breaking and wave energy attenuation (Lowe et al., 2005; Monismith, 2007; Ferrario et al., 2014). These protective services, however, depend on reef parameters such as depth, width, structural complexity and roughness, which are intimately related to the health of the coral (Harris et al., 2018). Yet, reefs continue degrading all around the world, from increasing temperatures, storm damage and poor management (Bellwood et al., 2004). The widespread loss of reef-building corals leads to loss of architectural complexity and 'reef flattening' (Alvarez-Filip et al., 2009), which affects the capacity of coral reefs for dissipating wave energy (Quataert et al., 2015; Harris et al., 2018) and keeping pace with the rising sea levels (Graham et al., 2015; Perry et al., 2018). Climate change through SLR, higher waves, and coral degradation will further increase wave runup in reef environments (Quataert et al., 2015). These factors jeopardize the substantial global risk reduction services that coastal communities receive from coral reefs at present (Beck et al., 2018).

Mainstreamed coastal policy and management approaches largely do not account for the contribution of environmental reef degradation to coastal risk. It is also broadly unknown whether the magnitude of this contribution relative to other threats such as SLR or the protection offered by other natural defenses, like dunes, which are more generally recognized for their coastal protection service and managed and restored accordingly. Only recently has research started to establish the risk reduction benefits of ecosystems (Narayan et al., 2017; Beck et al., 2018; Menéndez et al., 2018; Reguero et al., 2018b), but their combined effect, e.g., reefs acting with beach and dune systems, have only been assessed in terms of wave attenuation (e.g., Guannel et al., 2016) and not in terms of coastal risk, i.e., probability of socioeconomic losses, which are the metrics directly related to risk management strategies. These factors make it difficult to assess how these natural barriers work together for reducing risk to people and property and how intertwined their services are, while also hampering their consideration in risk management strategies.

This study focuses on the Mesoamerican Reef (MAR hereafter), the largest coral reef barrier in the western hemisphere. Understanding coastal flood risk and evaluating the risk reduction service of the MAR is critical not only for its conservation, but also for coastal risk management. The MAR precedes the eastern coastline of the state of Quintana Roo, Mexico, home to 1.5 million people (INEGI, 2015) and whose tourism sector contributes a $1.34 \%$ to Mexico's Gross Domestic Product. In Quintana Roo, uncontrolled and intense coastal development since the 1970s, particularly in Cancun, Cozumel, Isla Mujeres, Playa del Carmen and along the Mayan Riviera (Cancun to Tulum coastal stretch), have altered the natural coastal system and hence the resilience to extreme natural phenomena (Escudero-Castillo et al., 2014a). The area is also exposed to hurricanes and storms that produce recurrent flooding and erosion of settlements and assets on the beach front (Escudero-Castillo et al., 2014a; Mendoza et al., 2015), while anthropogenic interventions and degradation of ecosystems over wide extensions of these coasts have also driven chronic erosion and increased vulnerability to extreme weather events that put the people and the state's economy at risk (Escudero-Castillo et al., 2014a,b, 2018). However, the MAR is increasingly threatened by pollution, storm damage, ocean acidification, rising sea surface temperatures, disease outbreaks and unsustainable management practices (Mcfield et al., 2018). These factors put at risk the structural complexity and roughness of this natural barrier and jeopardize its capacity to dissipate wave energy.

This article addresses these questions and represents an advancement in how to account for the different drivers of coastal risk. The study focuses on assessing (i) how much and (ii) where the MAR prevents hurricane-flood damages to people and infrastructure, or in an equivalent manner, how reef degradation could increase coastal risk. This service is also compared relative to (iii) the protection offered by dunes, which are acknowledged and hence maintained and 
restored for their protection service, and (iv) the increased risk from SLR through its contribution to extreme flooding from hurricanes.

\section{MATERIALS AND METHODS}

\section{Overview}

This study quantifies the coastal flood risk reduction provided by the MAR for people, buildings (or built capital), and hotel infrastructure in Quintana Roo, Mexico. To assess this risk reduction benefits, we followed the expected damage cost avoided approach that estimates the benefits by their avoided flood damages. The main steps are described below and represented in Figure 1. Coastal flood risk is defined by the hurricaneinduced flood hazard and their damage to people and built infrastructure. The flood hazard is defined from a synthetic generation of storms ( $\sim 15,000$ storms) based on the historical distribution of hurricanes in the Caribbean. The effect of reefs on flooding is modeled through a numerical model that accounts for the complex transformation of waves in reef environments. The flood damages for each storm are quantified based on the flood heights of each storm and using vulnerability curves that relate the intensity of flooding with the degree of damage to the infrastructure. Risk is then quantified as the statistical description of these damages in terms of people affected and dollar-value damaged (buildings and hotels) and for different probabilities. The economic impacts include both direct and indirect losses. The flood risk reduction benefit of the MAR is estimated by calculating the difference in damages between two scenarios: current coral reefs and a scenario that assumes degraded coral reefs.

This approach follows and advances methods recently used to assess the risk reduction benefits of ecosystems (Beck et al., 2018; Menéndez et al., 2018). However, in this study, the risk reduction of the MAR is also compared with two other drivers of risk: (i) the increased hurricane flood risk produced by SLR and (ii) the effect of losing the dunes. The effect in risk of SLR is modeled by including local SLR projections to each hurricane. The effect of dunes on risk is estimated in a similar manner as applied to coral reefs (Figure 1).

\section{Hurricane Flood Hazard}

The probability of damages to people and buildings was calculated by generating synthetic hurricanes in the Caribbean. A stochastic generation of storms was needed because is not possible to calculate statistics of losses from a single damage scenario or a limited number of historical storms, where probability would remain uncertain (Resio and Irish, 2015). The simulations of $\sim 15,000$ synthetic storms were generated based on the historical storms ( $\sim 900$ historical storms) using a stochastic simulation of origins and wind speeds and modeling the hurricane tracks through random walks. The analysis of storms was carried out with the open-source CLIMADA risk model using the hurricane and coastal modules (Reguero et al., 2018b; Aznar-Siguan and Bresch, 2019).
For each of the synthetic storms, we calculated the wind, wave, and surge fields using global bathymetry from GEBCO and ETOPO in deep waters (National Oceanic, and Atmospheric Administration [NOAA], 2006) and the parametrical models implemented in CLIMADAś coastal module, following methods previously used in Reguero et al. (2018b). For the wind field, the model uses a non-symmetric fields model (Bretschneider, 1990). Wind waves generated by the wind field are calculated as the average of two different models (Young, 1988; Bretschneider, 1990). The storm surge was calculated by linearly adding the barometric surge and wind setup produced by the storm (Dean and Dalrymple, 1991). The rise of water above astronomical on the forereef takes into account the combined effects of direct onshore and alongshore wind stress on the surface of the water. The shear stress produced by the wind on the sea surface generates an elevation of the water level at the coastline, which can be described by the long wave equation, resolved on coastal transects (Dean and Dalrymple, 1991). Storm surges values were also obtained with the modeled surges from the MATO hydrodynamic model (Posada et al., 2008) as applied in Escudero-Castillo et al. (2014b), using surge levels calculated stationary conditions of winds to interpolate surge levels for any storm. The final storm surge values were calculated as the mean value of the surge levels from the analytical solution and the numerical simulations. These simplified approaches include uncertainty, particularly in nearshore areas, although they are a good estimate at the forereef. The significant wave height and surge levels offshore associated with a 100-year return period were compared with existing estimates of surge levels for the region of up to $2 \mathrm{~m}$ in Valdez (2010) and significant wave heights up to $15 \mathrm{~m}$ in Meza-Padilla et al. (2015), showing a good agreement (Supplementary Figure 1).

\section{Modeling Flooding and the Effect of Reefs}

Given the scope of the study and the availability of data, the flooding analysis had to be limited to the section of Quintana Roo with available information on coral reef presence and bathymetry. The region of study is shown in Figure 2 and comprises the mainland section of the MAR, but leaves out the island of Cozumel and other sections offshore and northwards where the coral reef bathymetry does not exist. For this region, high resolution bathymetry and coral cover data were available via CONABIO (Comisión Nacional para el Conocimiento y Uso de la Biodiversidad) from the 'Sistema Nacional de Información sobre Biodiversidad", which provides $4-\mathrm{m}$ resolution bathymetry and seabed cover from Cabo Catoche to Xcalak. The fore reef and beach profiles were assumed equal for all the coastal transects, based on mean slope values observed in the region (EscuderoCastillo et al., 2014b, 2018).

Flooding inland and the effect of reefs were modeled through XBeach, a wave propagation model that is able to calculate wave runup onshore but also the contribution to flooding of time-dependent long waves, which are particularly important in the surf zone of reef environments. This model has been

\footnotetext{
${ }^{1}$ http://www.conabio.gob.mx/informacion/gis/
} 


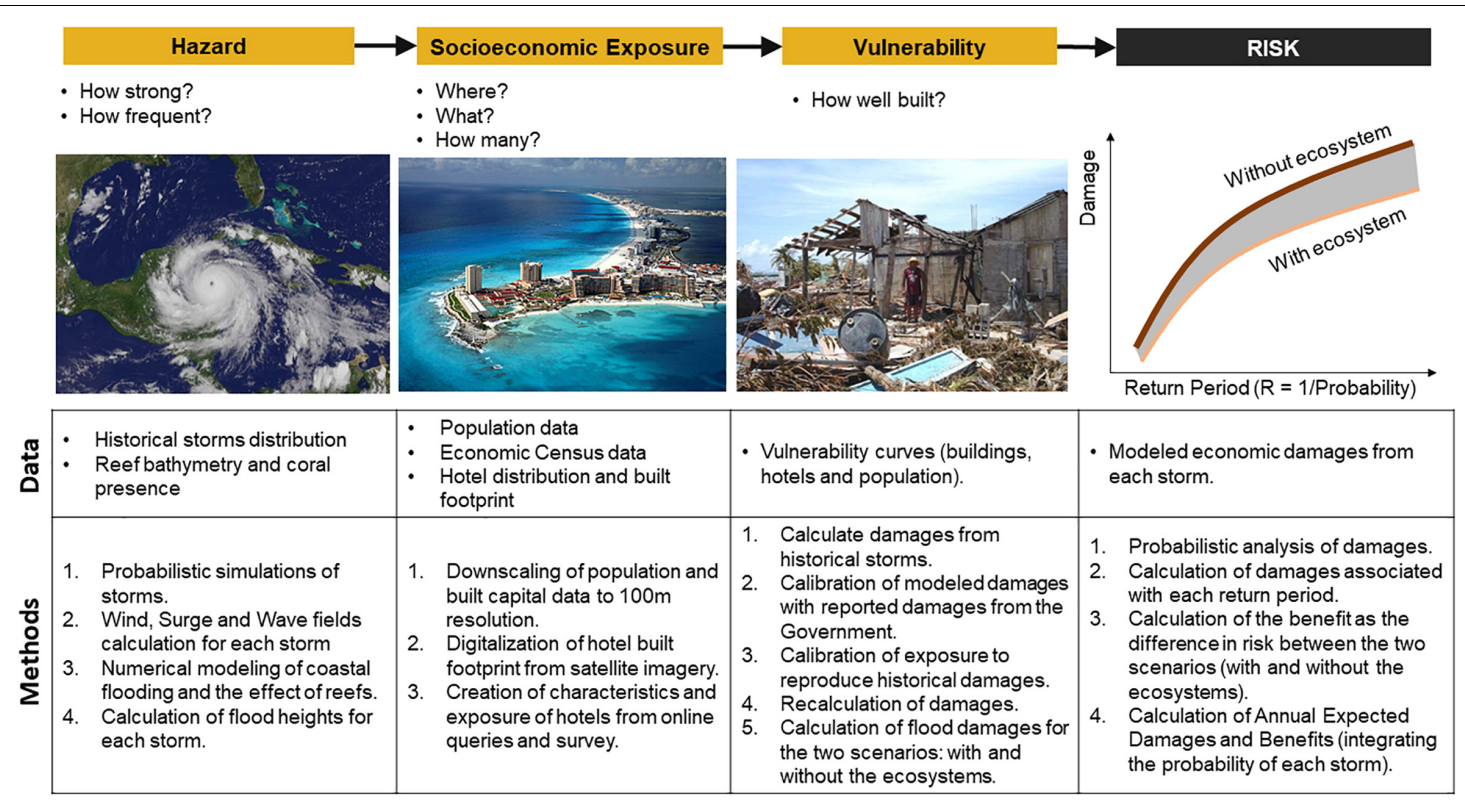

FIGURE 1 | Key steps and critical data needed to quantify risk. Source: adapted from Reguero et al. (2018b). Image 1: NASA GOES Blue Marble imagery by NASA's Earth Observatory Team. Image 2: Wikimedia Commons, by http://www.safainla.us/. Image 3: CENAPRED, (2007).

extensively validated for reef environments (van Dongeren et al., 2013; Quataert et al., 2015). The numerical model was run in coastal transects (a total of 2,515 transects), every $200 \mathrm{~m}$ along the coast (see Figure 2), with variable friction and in surf-beat mode. The application of a one-dimensional model neglects some of the dynamics that occur on natural reefs, such as lateral flow. However, it does represent a conservative estimate for infragravity generation and wave runup, as the forcing is shore-normal. In this case, the coastline and reef configuration show near-normally offshore waves (e.g., Figure 2). The friction coefficients were set based on a calibration of the model based on field data from (Quataert et al., 2015), and defined based on the seabed type classification for the region. The incident wave friction coefficient $\left(f_{\mathrm{w}}\right)$ and the current and infragravity wave friction coefficient $\left(c_{\mathrm{f}}\right)$, were applied to incorporate the effect of the roughness of the sea bottom on the decay of incident waves (van Dongeren et al., 2013). Coral reefs were given a value of $f_{\mathrm{w}}$ of 0.3 , whereas the rest of seabed types were given a friction value of 0.1 . The current and infragravity wave friction coefficient, $c_{\mathrm{f}}$, varied from 0.01 for sand to 0.15 for rocky coral reefs, whereas algae were given a value of 0.03 . Although the effect of seagrasses and algae was considered in the modeling, they provide less flood attenuation than coral reefs and their contribution was not isolated. However, research shows that in other areas they can also contribute to coastal protection, erosion control in particular (James et al., 2019). Examples of the transects with different bathymetric configurations are given in Figure 3.

The numerical model was run shore-normal, at each coastal transect for a subset of wave heights $\left(H_{\mathrm{s}}\right)$ covering the range between 1 and $10 \mathrm{~m}$ by $1 \mathrm{~m}$ increments, and sea levels ranging from 0 to $4 \mathrm{~m}$ (combination of mean sea level and storm surge) by $1 \mathrm{~m}$ increments. The modeled peak wave periods varied between 5 and $12 \mathrm{~s}$. The peak wave period was set constant due to computation limitations and because the effect of wave heights is more dominant on wave runup than the effect of wave periods. We selected $9.6 \mathrm{~s}$ for all simulations, which represents the $80 \%$ percentile of the peak periods calculated for all historical storms across the region. However, larger wave periods generate larger runup, and therefore this approach can be considered conservative for large wave periods at the cost of overestimating runup for sea-dominated storms. Nevertheless, storms with low periods also present smaller wave heights, which is the most influential variable for wave runup. The direction of waves was also considered orthogonal to each transect in the fore reef.

The flood levels onshore were reconstructed from the numerical simulations using multidimensional interpolation techniques based on radial basis functions that have been successfully applied to wave climate downscaling and wave overtopping in similar applications (Camus et al., 2011a,b; Guanche et al., 2013). The flooding levels onshore were interpolated using radial basis functions, which were trained taking as inputs the different wave heights, and surge levels at the forereef, and outputs the flooding levels simulated with the numerical model. This approach provided flooding levels for all the storms in each coastal transect. However, the approach does not consider horizontal effects in the propagation and flooding.

The scenario of a degraded reef from storm damage, pollution, and other factors was simulated assuming flattened and deeper reefs (Yates et al., 2017). The degraded reef was simulated by specifying in the numerical model: (1) an increase in depth for the reefs of $1 \mathrm{~m}$; and (2) reduced coral reef friction, assumed to be the same than the default sand values, per (Storlazzi et al., 2017). 

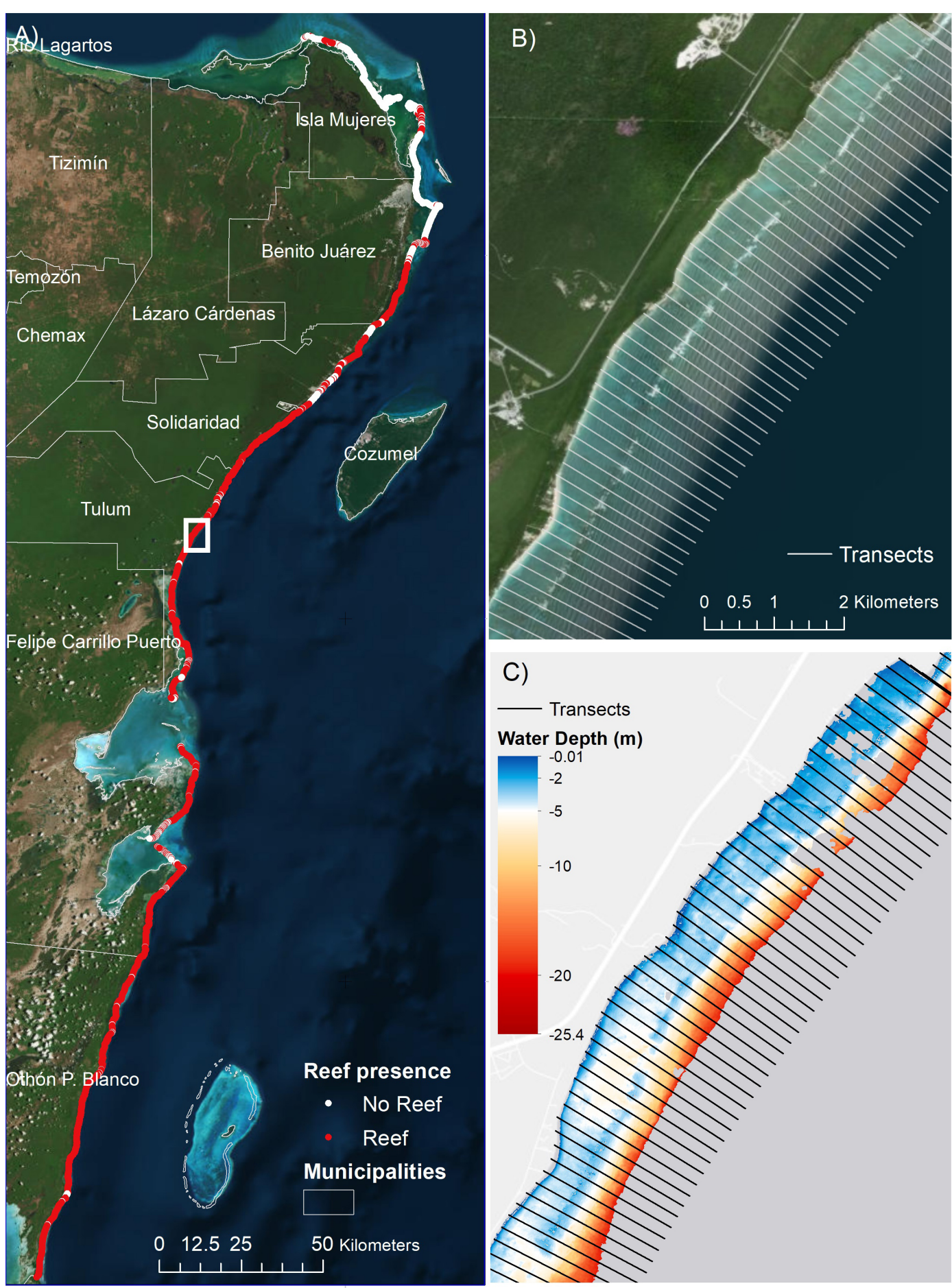

FIGURE 2 | Region of study and coastal transects. (A) Region of study, reef presence and costal transects coverage; (B) detail of coastal transects and satellite image showing the reef crest; and (C) details of bathymetry and coastal transects. The transects in (B,C) are spaced $200 \mathrm{~m}$ apart. The location for (B,C) is indicated in (A). Colors in (C) indicate water depths, in meters.

These assumptions are based on observed changes in degraded reefs. Observations in changes in seafloor elevation and volume for coral reefs in the Atlantic, Pacific, and Caribbean over the last several decades show significant regional loss of seafloor elevation and volume and are indicative of potential future changes in reefs (Yates et al., 2017). Evidences also show substantial flattening of reefs across the Caribbean as architectural complexity had declined non-linearly with the near disappearance of the most 
A

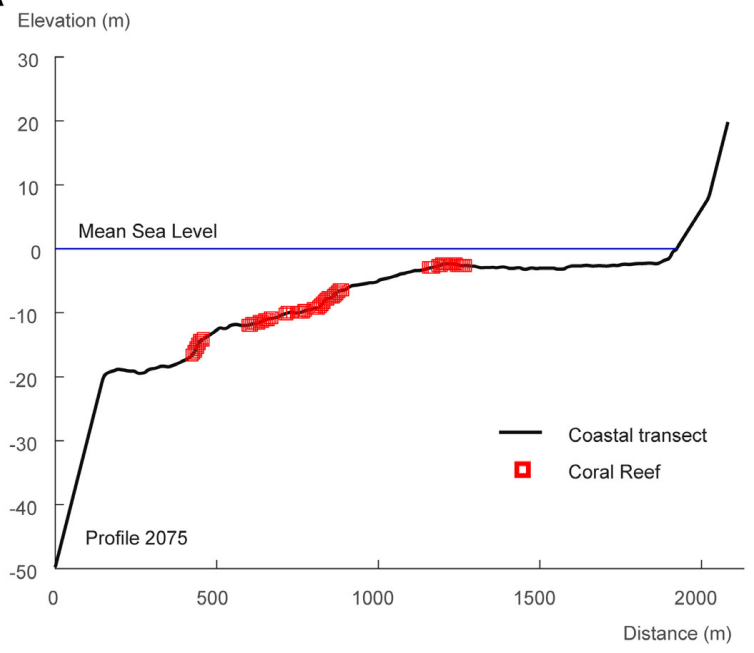

B

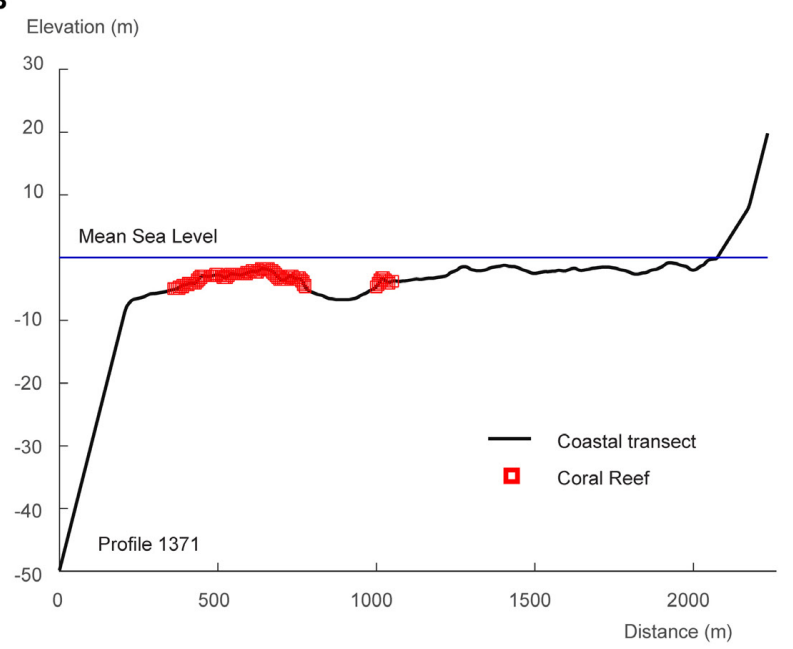

FIGURE 3 | Two examples of coastal transects for the reef model. The transect in panel (A) presents a deeper reef section, while panel (B) shows another transect with a shallower reef crest, followed by a reef lagoon.

complex reefs since 1969 (Alvarez-Filip et al., 2009). The loss of friction represents a severe flattening of the reef and reef matrix degradation, which are translated into frictional loss assuming that the reef will show a similar friction as the no-reef parts of the profile.

\section{Calculating People and Assets Damaged}

To calculate the consequences of flooding, data on people; built capital, which comprises residential, commercial and other infrastructure; and hotels were analyzed in spatial units of approximately $5 \mathrm{~km}$ and counted by ground elevations using the Shuttle Radar Topography Mission (SRTM) Digital Elevation Model, with a horizontal resolution of $90 \mathrm{~m}$ and vertical resolution of $1 \mathrm{~m}$ (Rabus et al., 2003; Farr et al., 2007). The total counts of people, built capital, and hotel infrastructure were then distributed between the coastal transects to infer damages by interpolating the flood levels with the potential socioeconomic exposure.

Population data were obtained from the WorldPop dataset with a spatial resolution of $100 \mathrm{~m}$ (Lloyd et al., 2017), represented in Figure 4. The spatial distribution and total counts of people were compared by municipalities with local census data and show a good agreement (Supplementary Figure 2). Built capital, or the value of buildings, was calculated based on global data from the 2015 Global Assessment Report (GAR) on Disaster Risk Reduction (UNISDR, 2015). The GAR data, with $5-\mathrm{km}$ spatial resolution, were downscaled to a resolution of $100 \mathrm{~m}$ using the population data and the government economic census that provides values of the residential, industrial, services and government buildings. The methods are based on approaches previously applied for risk quantification in data-poor environments (Reguero et al., 2015; Beck et al., 2018; Menéndez et al., 2018). To do this, first the residential capital stock per capita was calculated using data from GAR's Capital Stock and population (UNISDR, 2015).
Second, the per capita values were resampled to a resolution of $100 \mathrm{~m}$ and multiplied by the $100 \mathrm{~m}$-resolution population data (Figure 4). The industrial and commercial stocks were obtained similarly by dividing the urban and rural industrial capital from GAR by the total number of workers from the government census. The distribution of the different types of built capital is shown in Figure 5.

Impact on hotel infrastructure was calculated independently from built capital. Information on hotels was obtained from the economic census (INEGI, 2015) and online sources (Tripadvisor and Expedia) to create a database of hotel location, ranking, number of rooms, range and average prices, and other variables such as number of employees. The built footprint of each hotel along the coastline was digitized from Google Earth and satellite imagery in ArcMap (image available on May 2016). Hotels were classified into four categories based on their star rating. A predominance of 3.5- to 5-star hotels was observed in the northern coast of Quintana Roo, whereas the southern coast presents a high density of lower hotel rating, 2.5- to 3 -stars. The hotel distribution and number of rooms are represented in Figure 6.

To calculate the damages from flooding, the damage of each single storm is calculated by multiplying the value of exposure (dollar-value) by a percentage of property damaged, which is determined based on the flood heights generated by each storm at each coastal transect. The percentage of damage is determined from vulnerability curves for each type of asset (people, built capital, and hotels). For buildings, vulnerability curves were obtained by taking the average damage degree obtained from all the curves in the HAZUS-FEMA database (Scawthorn et al., 2006a,b) for each type of building: residential, commercial, and industrial types, respectively (see Supplementary Figure 3 ). For hotels, local vulnerability curves were developed based on historical damages for hurricanes Wilma and Dean, obtained from the Mexican National Center for Prevention of Disasters 


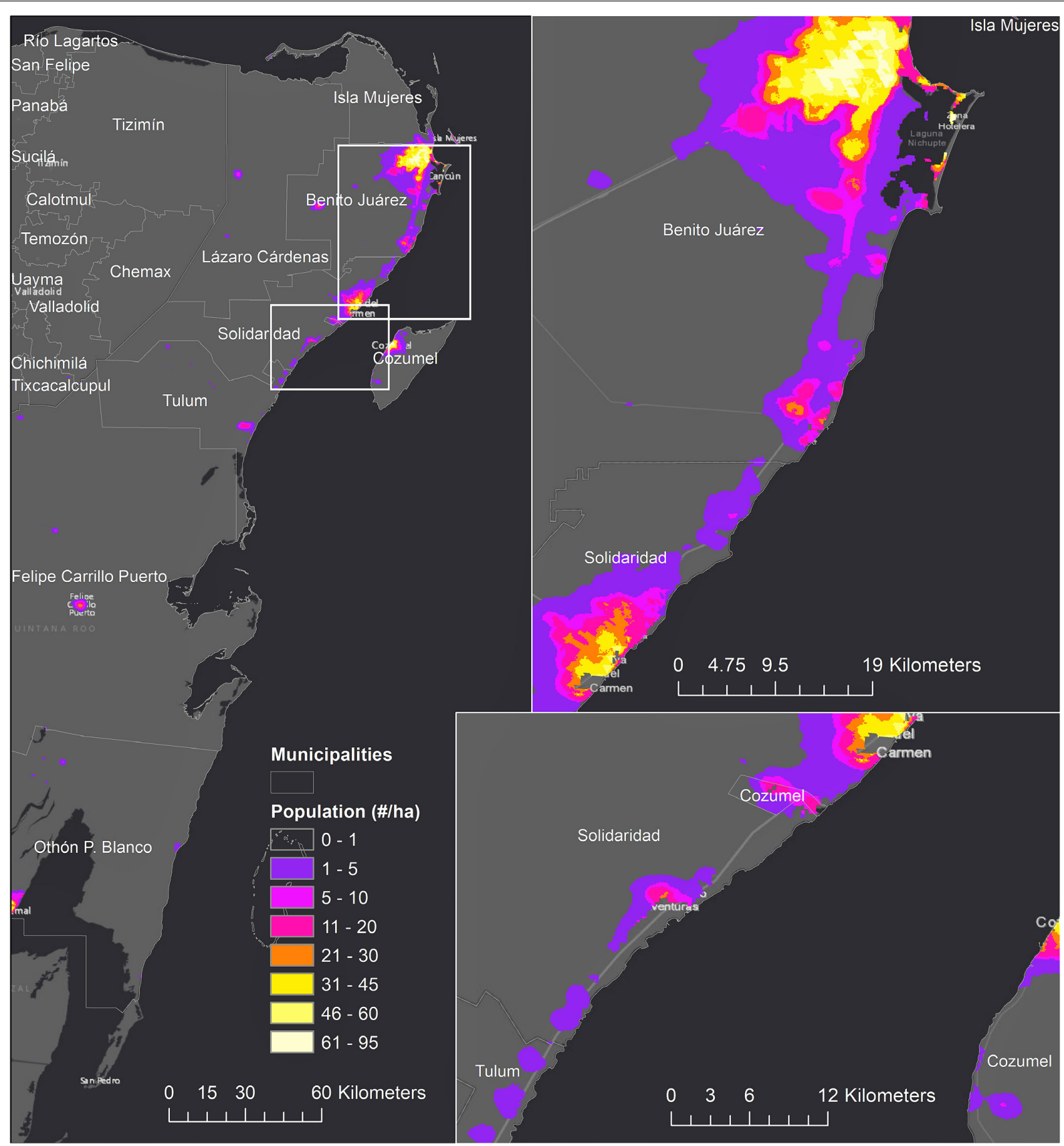

FIGURE 4 | Population distribution. Values are expressed in number of people per hectare.

(CENAPRED) and the Economic Commission for Latin America and the Caribbean (CEPAL). Damage costs were expressed in US Dollars (USD) per square meter of the flood plain as a function of the hotel star-rating, using the reported losses in terms of number of damaged hotel rooms after each event and the estimated surface area of each hotel room (see Supplementary Figure 4).

Given the uncertainties in the risk modeling (e.g., exposure data, hazard definition, flooding approach, and vulnerability curves), the model was calibrated to represent the reported losses for historical hurricanes, which are surveyed and reported after each storm season by the CENAPRED. The exposure was calibrated over the region so that the modeled direct losses for Hurricane Dean would match the official economic damages reported by the Government for the same storm. Hurricane Dean was selected between the available historical events with official damage estimates as a benchmark because its damages $(\sim 214$ million USD in 2007) were predominantly driven by coastal flooding and impacted significant residential infrastructure, as opposed to other storms, such as Wilma and Emily in 2005, 


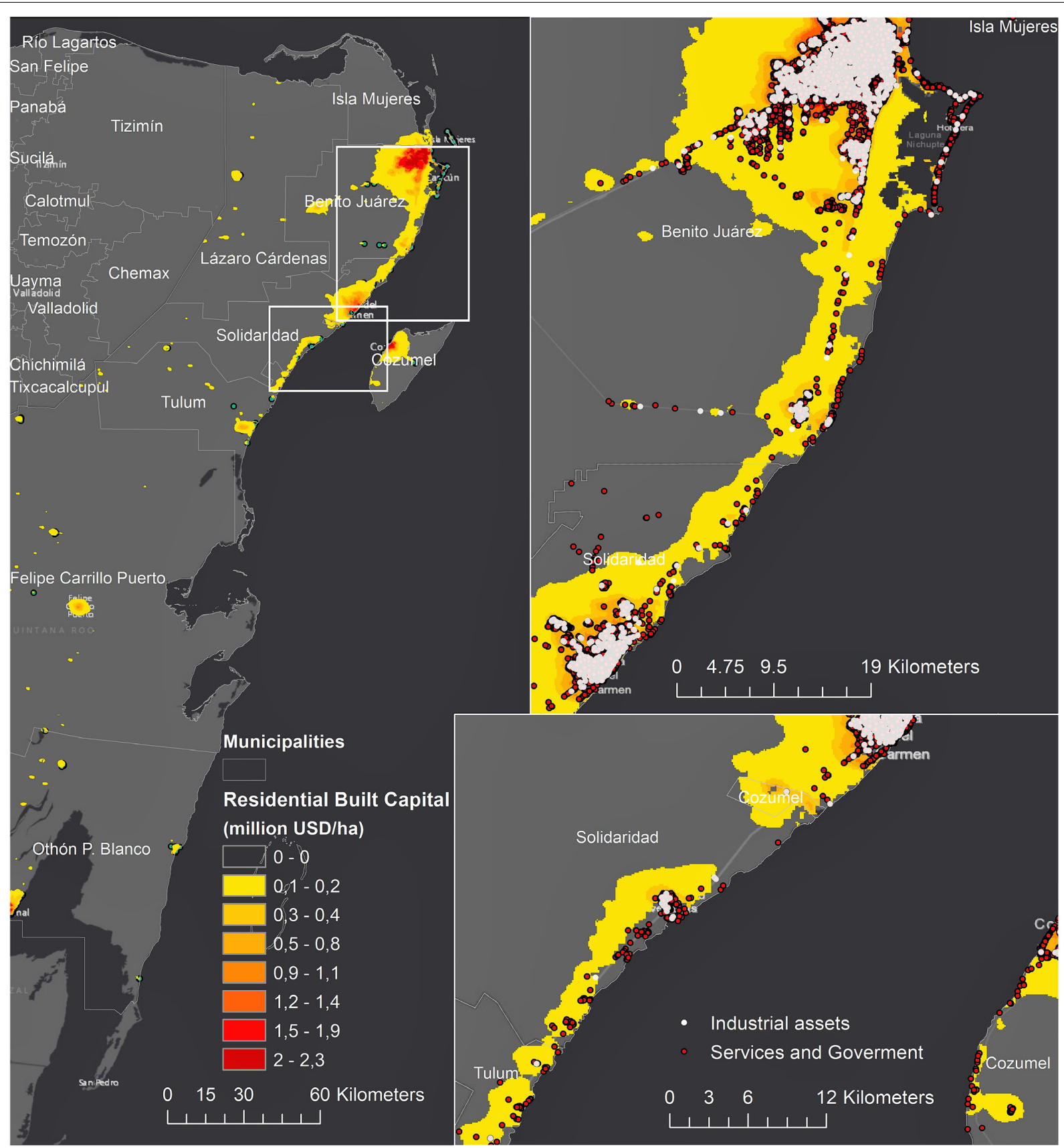

FIGURE 5 | Distribution of built capital. Values are expressed in million USD value per hectare.

where a significant fraction of the damages were caused by wind and rainfall and the losses were mostly concentrated on the tourism sector.

\section{Estimating Indirect Damages}

We also estimated indirect damages, which are economic losses caused by the consequences of physical destruction caused by flooding such as business interruption, tourism impact, etc. Estimates of the indirect damages were based on the review of impacts of historical storms in the region produced annually by
CENAPRED. Indirect damages were calculated by multiplying the modeled direct damages with an average ratio of indirect over direct damages for three historical Hurricanes: Emily in (2005), Wilma in (2005), and Hurricane Dean in (2007). Values of direct and indirect damages for the three storms were obtained from CENAPRED reports and converted to USD for each corresponding year using historical conversion rates and then to USD-value in 2015 correcting for the historical buying power.

According to surveys from the Government, Hurricane Dean in (2007) produced $40 \%$ additional damages in indirect impacts 


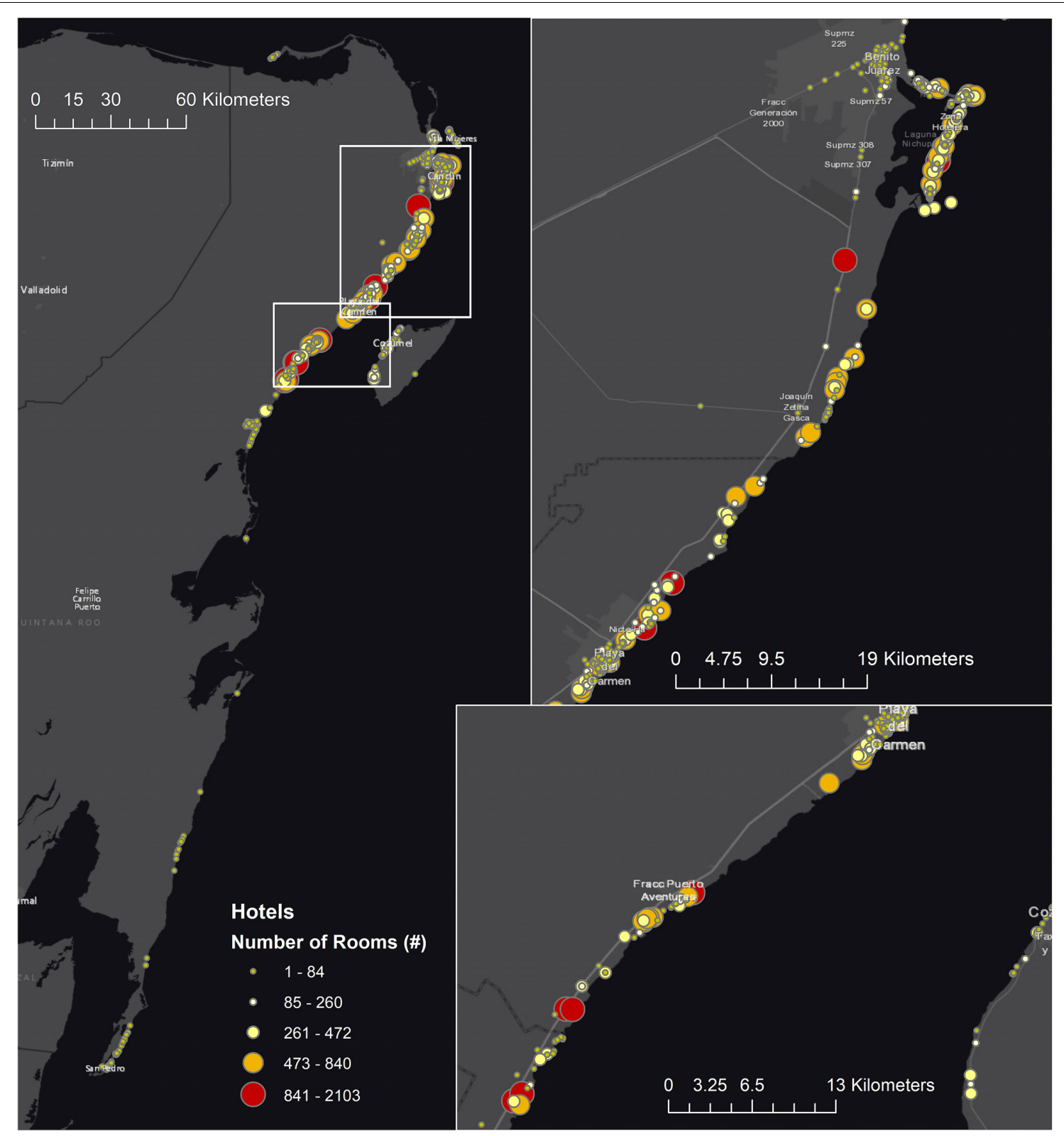

FIGURE 6 | Hotel distribution in Quintana Roo coastal zone by the number of rooms.

(0.4 factor), Wilma in (2005) had three times more indirect damages than direct damages, and Emily in (2005) produced 1.6 times more indirect damages than direct damages. Based on these measured values, the indirect damages are on average 1.6 times the direct damages, although it shows a large range of variation. However, evidence suggests that the proportion of indirect impacts increases in larger disasters, as seen with Hurricane Wilma in comparison with Emily, although both impacted the same region. This is because business interruption and other indirect effects are proportionally larger after stronger storms. However, in absence of better data, here we used the average factor, $\mathrm{x} 1.6$, and applied it linearly to all the storms although we acknowledge that the indirect damages may constitute a larger fraction of total losses in larger disasters than in smaller ones.

\section{Calculation of Reef Benefits}

The flood risk reduction from coastal ecosystems was estimated through the avoided damage or expected damage function methods (Samonte-Tan et al., 2007; Barbier, 2015). The approach compares the additional people and property affected if existing coastal ecosystems were lost. This approach, therefore, represents the risk reduction benefits of the protection that ecosystems offer, but it can also be seen as the increase in risk from environmental degradation. Risk is described using (i) an estimate of the annual average costs of flooding, or annual expected damage (AED), and 
(ii) the damages associated with different storm return periods (i.e., the average recurrence interval, in years, of each event). The damages for the different return periods are interpolated from the damage exceedance frequency curve at each coastal transect using the probability associated to different return periods. The damage probability distributions were calculated through cumulative frequency analysis of all the damages produced by storms at each location. The AED is calculated by weighting the loss of each storm by its probability of occurrence. The economic risk reduction benefits are provided in 2015 USD and risk reduction for the population in total number of people protected.

\section{The Effect of Dunes in Coastal Risk}

The risk reduction service of the MAR was compared with the relative contribution of dunes for flood risk reduction to better understand the reef's relative importance for flood prevention across the region. The effect of the dunes was estimated by including the dune height in the flood model and calculating flooding damages only if the dune heights were overtopped. The effect of dunes in coastal risk was calculated by comparing the simulated losses with and without dunes.

Dune elevation and width were estimated from Lidar data provided by the INEGI (Instituto Nacional de Estadística y Geografía de México) for the year 2007, with a horizontal resolution of $5 \mathrm{~m}$. Dune heights vary between 0.5 and $4 \mathrm{~m}$ (Supplementary Figure 5). However, in contrast with the reef bathymetry, the Lidar topographic data did not cover the entire region (only from Punta Nizuc to south of Punta Maroma). The remaining dune elevations were estimated from satellite imagery and associating the elevation from similar sections of beach and dunes covered in the Lidar data.

Lack of data in dune vegetation did not allow considering the effect of dune vegetation in attenuating the wave run up and overtopping, although recent research shows that it can provide a reduction of wave-run up erosion of $40 \%$ (Feagin et al., 2019). Erosion of dunes under large storms was also not considered although it could reduce the effectiveness of dunes should they breach. For these reasons, the valuation for dunes carries higher uncertainty than for the MAR and is only used for comparative purposes.

\section{The Effect of Sea-Level Rise in Coastalz Risk}

The effect of SLR was including in the flood model as a static increase in the mean sea level in every storm. The damage from each coastal storm was recalculated similarly to the without SLR scenarios, at each coastal transect and using a new mean sea level that corresponded to a SLR projection by the end of the $21^{\text {st }}$ century. The new simulated damages were analyzed statistically to define losses associated with different return periods, as applied to the risk without SLR. The local SLR was obtained from the mean value of the Representative Concentration Pathway (RCP) 4.5 by the end of the $21^{\text {st }}$ century and interpolated at each coastal transect (Church et al., 2013). The RCP4.5 projects a mean SLR for Quintana Roo of $\sim 0.5 \mathrm{~m}$ (with lower and upper bounds of projections being 0.29 and $0.75 \mathrm{~m}$, respectively), whereas the average estimate for the RCP 8.5 is $0.7 \mathrm{~m}$. The assumption of the RCP 4.5 is, therefore, a conservative one. The SLR was used to recalculate the flooding of all hurricanes. Other effects of climate change, such as changes in the hurricane intensity or frequency, were not included to isolate the effect of SLR in flooding and compare its effect on risk with reef degradation. Once the projected flood heights were calculated, the assessment of flood risk followed the same approach as above.

The effect of SLR was studied in terms of changes in damages (changes in losses and people impacted for different probabilities), but also in terms of changes in the flood hazard (i.e., variations in total water levels onshore) because the reef provides different flood attenuation depending on the specific wave and sea level conditions of each storm. To assess the effect of SLR in the flood hazard, we calculated attenuations for each storm under two scenarios of mean sea level: present sea level and sea-level rise, as:

Attenuation $=[$ flood level without the reef for storm i $] /[$ flood level with the reef for storm i] - 1 .

The attenuation values were summarized by the mean and the 25 - and $75 \%$ percentiles, to then calculate the ratio between the mean attenuation with sea-level rise and with present sea level.

\section{RESULTS}

\section{Flood Hazard Damage Prevention by the Mesoamerican Reef in Quintana Roo Distribution of People and Economic Exposure in the Study Area}

$38 \%$ of the total of 1.5 million people living in the State of Quintana Roo, 570,670 people, live in the coastal zone, defined as the flood-prone area close to the shoreline and below $20 \mathrm{~m}$ in elevation. The population and infrastructure located in the study area (with coral reef and bathymetry data) totals 307,640 people and over 3.3 billion USD in built capital, concentrated primarily in the northern portion of Quintana Roo (Figures 4, 5). However, only $26 \%$ of the built capital ( 869 million USD) and $34 \%$ of these people $(105,800)$ are located inshore of a coral reef. For example, Cancun, the most intensively developed area, is not protected by reefs (Escudero-Castillo et al., 2018). However, the fraction of hotel infrastructure situated onshore of coral reefs is comparatively larger than for other types of buildings; $63 \%$ of the hotel infrastructure is inshore of coral reefs (Figure 6).

\section{Historical Hurricanes}

The MAR has provided significant protection against historical hurricanes. During Hurricane Dean in (2007), which made landfall on the Yucatan Peninsula as a powerful Category 5 storm and produced $\sim 175$ million 2015 USD in direct damages (CENAPRED), the MAR prevented $43 \%$ of additional flood damage (Table 1). For hurricanes Wilma (category 5 at landfall, 2005) and Emily (category 4, 2005), coral reefs prevented 11 and $9 \%$ of flood damages respectively (Table 1). The damage prevention provided by coral reefs was lower for Hurricanes Wilma and Emily because they affected the northern portion of the State, which includes Cancun that is intensely developed but 
TABLE 1 | Socioeconomic benefits from the Mesoamerican Reef for historical hurricanes.

\begin{tabular}{|c|c|c|c|c|c|c|c|c|c|}
\hline Storm & $\begin{array}{l}\text { Modeled } \\
\text { people } \\
\text { flooded (\#) }\end{array}$ & $\begin{array}{c}\text { People } \\
\text { protected } \\
\text { by reefs (\#) }\end{array}$ & $\begin{array}{c}\% \text { of } \\
\text { modeled } \\
\text { impact }\end{array}$ & $\begin{array}{l}\text { Modeled damage } \\
\text { to built capital } \\
\text { (million USD) }\end{array}$ & $\begin{array}{c}\text { Benefit of } \\
\text { protection } \\
\text { (million USD) }\end{array}$ & $\begin{array}{c}\% \text { of } \\
\text { modeled } \\
\text { impact }\end{array}$ & $\begin{array}{c}\text { Modeled damage } \\
\text { to hotels (million } \\
\text { USD) }\end{array}$ & $\begin{array}{c}\text { Benefit of } \\
\text { protection } \\
\text { (million USD) }\end{array}$ & $\begin{array}{c}\% \text { of } \\
\text { modeled } \\
\text { impact }\end{array}$ \\
\hline Hurricane Dean in 2007 & 21,015 & 13,799 & $65.7 \%$ & 174.9 & 119.2 & $68.2 \%$ & 46.9 & 43.2 & $92.1 \%$ \\
\hline Emily in 2005 & 124,537 & 13,683 & $11.0 \%$ & $1,439.6$ & 155.8 & $10.8 \%$ & 179.6 & 82.1 & $45.7 \%$ \\
\hline Wilma in 2005 & 168,859 & 15,766 & $9.3 \%$ & $2,075.9$ & 181.0 & $8.8 \%$ & 265.5 & 91.8 & $34.6 \%$ \\
\hline
\end{tabular}

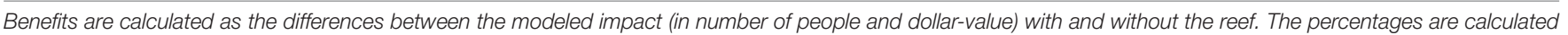
by dividing the savings over the modeled impact.

not directly protected by reefs, and they were also characterized by strong rainfall (Escalante-Mancera et al., 2009; Silva et al., 2009). Meanwhile, Hurricane Dean impacted the southern section and affected predominantly residential houses and coastal population, while most of the damages were directly produced by coastal flooding.

For the same reasons, the estimates of people protected for reefs are also higher for Hurricane Dean; the MAR prevented $\sim 66 \%$ more people from being affected by flooding (Table 1). Despite the different characteristics and exposure distribution of the three storms impact areas, the MAR protected consistently between 13,688 and 15,766 people from flooding during those storms. The protection for hotels, however, was significantly larger than for people and built capital. The estimated benefits for hotels in flood damage prevention range from $34.6 \%$ from Wilma to $92.1 \%$ for Dean, valued at 43.2 and 91.8 million USD respectively (Table 1). The economic protection of the MAR for hotels was also higher for Hurricanes Emily and Wilma than for Dean because the distribution of hotels is closer to the coastline than other buildings and coastal communities (Figure 6).

\section{Probabilistic Coastal Risk Reduction}

The risk reduction benefits of the MAR are also assessed probabilistically across storms frequency. The risk is described by the direct damages to people, building and hotel infrastructure across return periods, and also calculated as AEDs. The risk reduction potential of the reefs is represented in Figure 7 and summarized in Table 2. The modeled damages with current reef condition and with degraded reefs for population, built capital and hotel infrastructure are included in Supplementary Tables 1-3. The results for people (Figures 7a,d and Table 2) indicate that reefs protect $\sim 4,600$ people per year on average, which represents $4.3 \%$ of the people living inshore of a reef. The people protected is twice as much for a 1-in-100-year event. However, if reefs were degraded, the AED could more than double (increase of 195\%), and the 1-in-100-year would affect $41.7 \%$ more people.

In terms of built capital (Figures $7 \mathbf{b}, \mathbf{e}$, Table 2, and Supplementary Table 2), the MAR protects $1.9 \%$ of the total built capital value behind reefs per year. Its value is estimated in $\sim 16$ million USD per year in direct avoided flood damages, but assuming average ratios of indirect damages, reefs provide an additional protection of $\sim 26$ million USD in averted indirect losses per year. Overall, this totals an estimated value of 42 million USD savings in flood protection per year. However, reef degradation could more than double AED (increase of 178\%), while the 1-in-100-year risk would increase by $74 \%$, by $\sim 100.7$ million USD of additional damage (Figure $7 \mathbf{b}$ and Table 2 ).

Hotels benefit most from the effects of the MAR on flood prevention; the modeled direct losses and the benefits for the hotel infrastructure are provided in Table 2 and Supplementary Table 3 . Hotels receive $\sim 21$ million USD per year in direct averted flood damages (without accounting for indirect damages). However, reef degradation could more than double the AED ( $\sim 173 \%$ increase; Figure $7 \mathbf{f}$ and Table 2$)$; from 12 million USD per year to 33 million USD per year. The 1-in-100-year flood risk would increase by $91 \%$, or by $\sim 323$ million USD (Figure 7c and Table 2). These benefits relative to the built capital value in the coastal zone represent between $2.4 \%$ per year to $50 \%$ of the built capital for a 1-in-500-year flood damage (Table 2 and Supplementary Tables 1-4).

\section{Spatial Distribution of Risk Reduction Benefits}

The spatial distribution of the annual expected benefits for people, built capital and hotel infrastructure, respectively, are shown in Figures 8-10 The maps identify where this protection is more valuable and reveals that the most protection to economic assets and people do not always coincide.

The benefits for people are concentrated in the urban areas of Puerto Morelos (in Benito Juarez) and south of Cancun (Figure 8). However, protection for the built capital also concentrates in Playa del Carmen. This difference demonstrates the protection in Playa del Carmen is not only for residential buildings, but also to commercial and other buildings. In that region, there are benefits of more than 0.5 million USD for 200-m long sections of reef, which represents over 2,500 USD per alongshore linear meter of reef, per year. However, the comparison with the benefits for hotel infrastructure indicates a different pattern. The protection of MAR is more homogenous along the coastline and concentrates the largest benefits in the district of Solidaridad, followed by Playa del Carmen.

\section{Risk Reduction Effects of Dunes}

To better understand the risk reduction of the MAR with respect to other drivers of risk, we compare the coral reefs' benefits with the risk reduction provided by dunes. The dunes are assumed to provide protection up to the elevation they are overtopped during a storm or hurricane. Their risk reduction benefit is determined by comparing two scenarios: with and without dunes, as applied to coral reefs.

The risk at present and the risk reduction benefits of dunes are presented in Supplementary Table 4. Regionally, the annual 
A

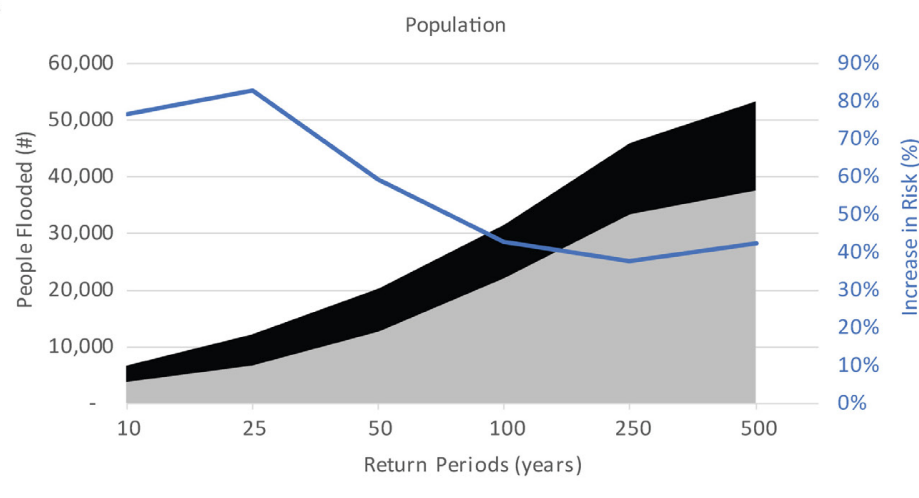

Current reef Degraded reef - 'Increase in risk from reef degradation'

B

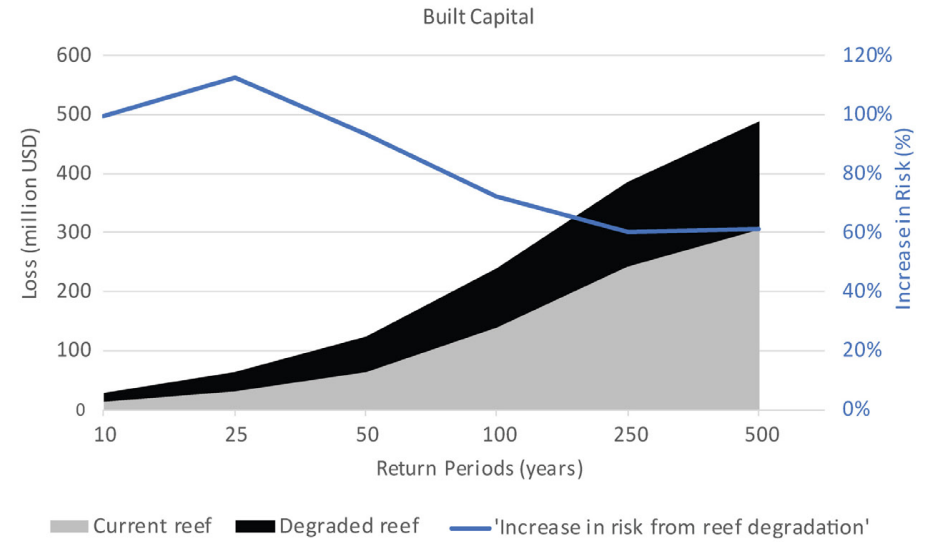

C

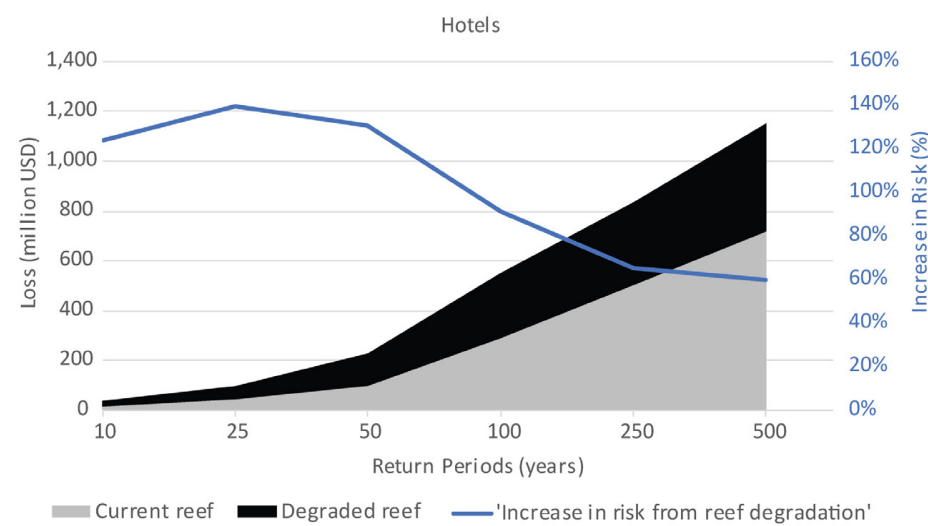

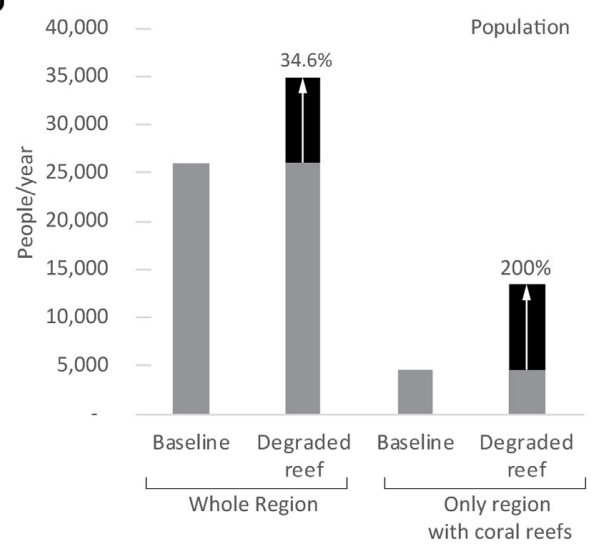

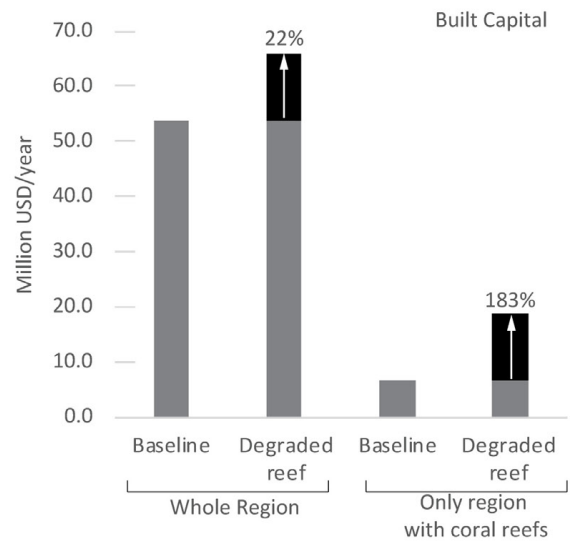

$\mathbf{F}$

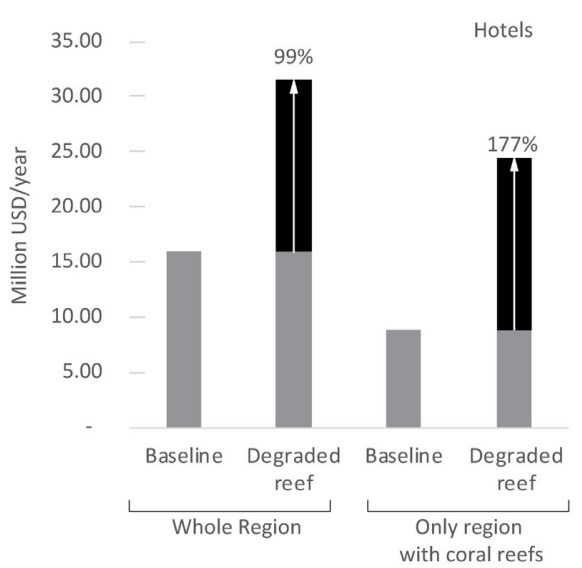

FIGURE 7 | Coastal risk and the risk reduction of the Mesoamerican Reef. Risk is represented as people flooded (a,d), damages to built capital (b,e), and damages to hotel infrastructure $\mathbf{( c , f ) . ~ T h e ~ d i f f e r e n c e ~ i n ~ t h e ~ g r a p h i c s ~ ( i n ~ b l a c k ) ~ r e p r e s e n t s ~ t h e ~ p r o t e c t i o n ~ o f f e r e d ~ b y ~ t h e ~ M e s o a m e r i c a n ~ R e e f . ~ R i s k ~ i s ~ r e p r e s e n t e d ~ a c r o s s ~ r e t u r n ~}$ periods (a-c) and in terms of annual expected damages (AEDs) (d-f). A return period of $n$ years represents a probability of occurrence of $1 / n$ years. The increase in risk, showed by a solid blue line in the left panels, indicates how much risk will increase from reef degradation, in percentage over the baseline risk, or risk with 'current reef' (gray shading). It is calculated as the benefit (black shading) divided over the baseline risk (gray shading). For (d-f), the bars on the left represent flood risk for the whole of the region, whereas the bars on the right represent only the values for the subset of transects with coral reefs (excluding transects with no coral reefs). The annual percent increase in losses is annotated in each case and calculated with respect to the baseline scenario. Values for each type of population, built capital and hotel infrastructure are included in Supplementary Tables 1-3, respectively.

benefit of the dunes in Quintana Roo is estimated at more than 16.7 million USD per year. Considering only sections with coral reefs, the annual benefit for built capital provided by dunes is 4.7 million USD, whereas the risk reduction benefit from reefs for the same region is four times larger, over 16.6 million USD per year. 
TABLE 2 | Population, built capital, and hotel infrastructure protected by reefs.

\begin{tabular}{|c|c|c|c|c|c|c|c|}
\hline \multirow{2}{*}{$\begin{array}{l}\text { Risk reduction offered by } \\
\text { the mesoamerican reef }\end{array}$} & \multirow{2}{*}{$\begin{array}{l}\text { Annual } \\
\text { expected } \\
\text { damage }\end{array}$} & \multicolumn{6}{|c|}{ Storm return period } \\
\hline & & 10 years & 25 years & 50 years & 100 years & 250 years & 500 years \\
\hline \multicolumn{8}{|c|}{ Risk reduction benefit offered by reefs } \\
\hline Population (\#) & 4,586 & 2,677 & 5,140 & 6,941 & 8,796 & 10,784 & 13,478 \\
\hline Built capital (million USD) & 16.3 & 13.8 & 33.8 & 56.8 & 100.7 & 130.7 & 171.7 \\
\hline $\begin{array}{l}\text { Hotel infrastructure (million } \\
\text { USD) }\end{array}$ & 20.8 & 20.8 & 58.4 & 130.5 & 262.6 & 332.1 & 431.5 \\
\hline \multicolumn{8}{|c|}{ Percentage increase in risk compared to baseline risk } \\
\hline Population & $195.5 \%$ & $74.4 \%$ & $81.1 \%$ & $57.9 \%$ & $41.7 \%$ & $33.5 \%$ & $37.8 \%$ \\
\hline Built capital & $178.2 \%$ & $96.9 \%$ & $111.7 \%$ & $91.4 \%$ & $74.0 \%$ & $56.0 \%$ & $57.5 \%$ \\
\hline Hotel Infrastructure & $173.3 \%$ & $123.8 \%$ & $139.2 \%$ & $131.0 \%$ & $91.2 \%$ & $65.6 \%$ & $60.0 \%$ \\
\hline \multicolumn{8}{|c|}{ Percentage increase in risk compared to the total exposure in the coastal zone } \\
\hline Population $(*)$ & $4.3 \%$ & $2.5 \%$ & $4.9 \%$ & $6.6 \%$ & $8.3 \%$ & $10.2 \%$ & $12.7 \%$ \\
\hline Built capital $(* *)$ & $1.9 \%$ & $1.5 \%$ & $3.8 \%$ & $6.5 \%$ & $11.6 \%$ & $15.1 \%$ & $19.8 \%$ \\
\hline Hotel infrastructure $(* *)$ & $2.4 \%$ & $2.4 \%$ & $6.7 \%$ & $15.0 \%$ & $30.2 \%$ & $38.2 \%$ & $49.7 \%$ \\
\hline
\end{tabular}

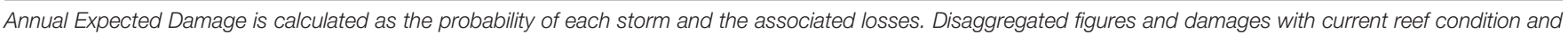

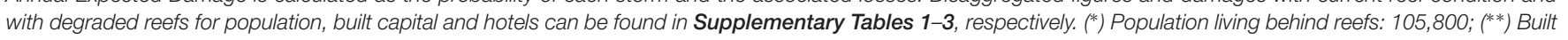
capital behind reefs: 858 million USD.

TABLE 3 | Increase in risk for built capital from reef degradation and sea level rise.

Built capital (million USD)

protected in sections with reefs

\section{Annual expected} damage
Storm return period

\begin{tabular}{|c|c|c|c|c|c|c|c|}
\hline & & & & & & & \\
\hline & & 10 years & 25 years & 50 years & 100 years & 250 years & 500 years \\
\hline $\begin{array}{l}\text { Damage with current reef condition } \\
\text { (baseline) }\end{array}$ & 12.0 & 16.8 & 41.9 & 99.6 & 287.8 & 506.0 & 719.2 \\
\hline Contribution of losing the reef & 20.8 & 20.8 & 58.4 & 130.5 & 262.6 & 332.1 & 431.5 \\
\hline Contribution of sea level rise & 32.5 & 16.0 & 28.8 & 59.1 & 129.1 & 162.6 & 201.9 \\
\hline $\begin{array}{l}\text { Contribution of reef degradation } \\
\text { and sea level rise }\end{array}$ & 74.0 & 49.0 & 122.5 & 219.9 & 431.1 & 533.5 & 667.9 \\
\hline
\end{tabular}

However, the risk reduction benefits of dunes are most critical where there is no coral reef offshore and for small return-period storms. For example, for sections with both ecosystems, coral reef degradation would represent a 99\% increase in the 1-in-10-year risk, but dunes loss would represent a 264\% increase. Dunes provide 27.3 million USD protection across the region for the same storm probability, whereas the benefits of the reefs are 13.8 million USD (Supplementary Tables 2, 4). However, for the 1-in-100year storm, the benefit of dunes is 14.8 million USD, compared to 100.7 million USD from reefs, as reefs keep attenuating waves and flooding during intense storms, whereas dunes are overtopped.

\section{Effects of Sea-Level Rise on Coastal Risk}

Corals reefs provide significant flood reduction along the Quintana Roo coastline. The percentage increase in flood risk with degraded reefs is shown in Figure 11. The average increase in flooding varies from 20 to $120 \%$ between transects, with a mean value of $48 \%$, depending on different geomorphology but also the different hurricanes' waves and surges for each storm along the shoreline. The mean values across the region of the 25- and 75percentiles are 33.5 and $63.4 \%$, respectively. However, the reefs attenuate flood levels for specific storms up to $140 \%$, as shown by the 75-percentile of flood attenuation.

Rising sea levels and climate change will have a significant negative impact on the ability of coral reefs to mitigate the effects of coastal hazards in the future (Quataert et al., 2015). In principle, the contribution of SLR would render reefs less effective, as the water depth increases with all the remaining factors unchanged. In general, reefs will be less effective (ratio below the 1-value in Figure 11b), although there are also instances where reefs will provide more effective flood reduction with SLR (ratio above 1), as shown in Figure 11b. This can be explained by the different reef bathymetric configurations and their effects on flooding (e.g., Baldock et al., 2014).

The contribution of the reef degradation is larger than the increase in risk caused by SLR for population, built capital, and hotel infrastructure at risk (Figure 12). For example, for a 1-in10-year probability, SLR contributes 20.8 more million USD in risk to built capital versus 16.0 million USD of SLR (Table 3 ). 


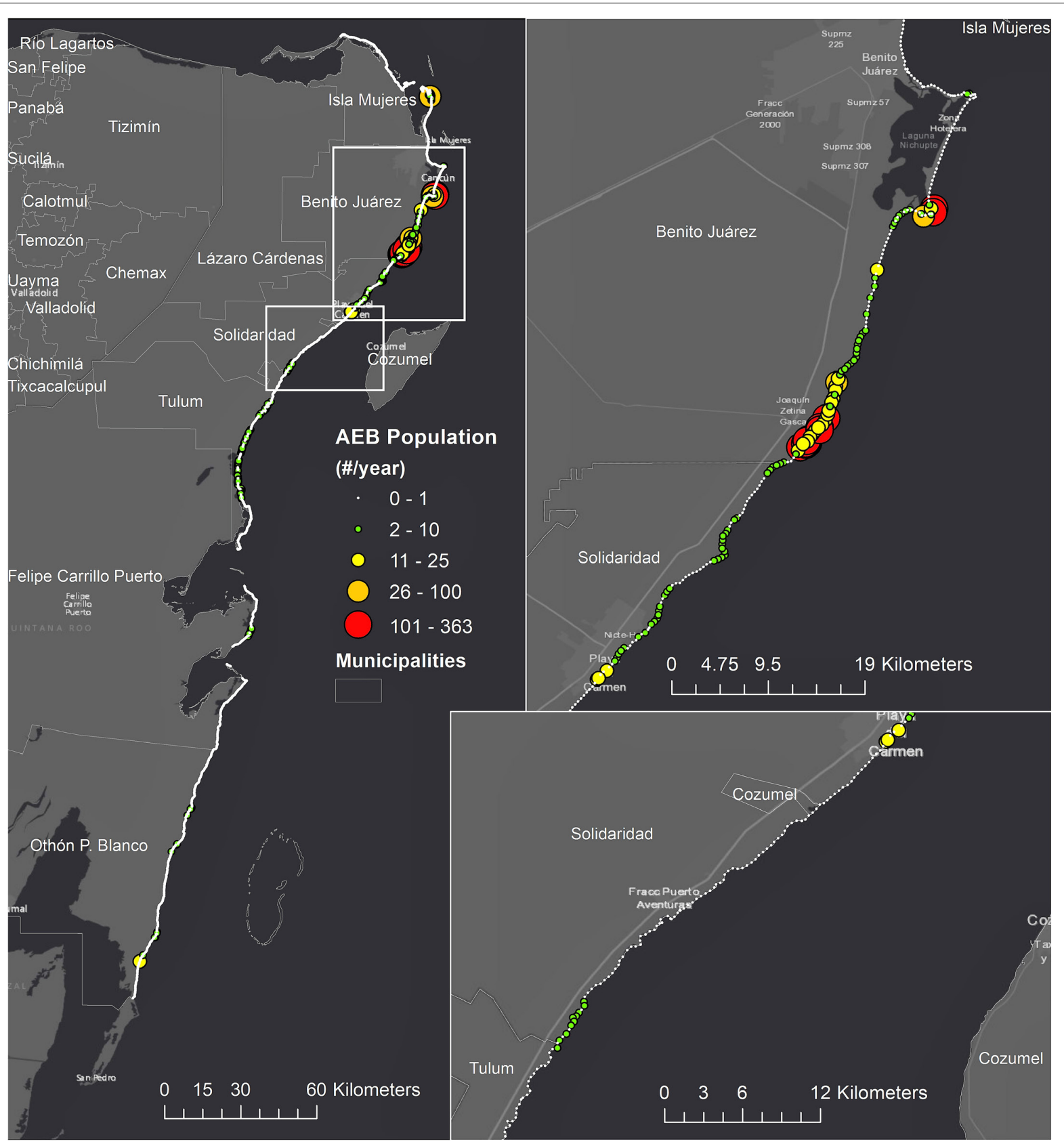

FIGURE 8 | People protected from flooding per year. The points represent the annual expected benefit to people, in each coastal transect spaced 200-m along the coastline.

However, in terms of AED, the contribution of SLR is larger than coral reef degradation (32.5 versus 20.8 million USD increase in risk). Furthermore, the combined contribution of SLR and reef degradation leads to damages larger than the linear addition of each driver. These two reasons point to SLR as a major driver of more recurrent damages. Indeed, SLR is the largest contributor to risk overall. Sea-level rise would increase hurricane flood risk by a factor of 1.8 times, from 72.3 million USD to 204.2 million USD, for a modest $(+0.5 \mathrm{~m}$, RCP 4.5$)$ increase in the mean sea level.

\section{DISCUSSION}

By integrating economic, ecological, and hydrodynamic models, this study shows the spatial risk reduction benefits of the MAR, locally and regionally. The MAR provides substantial risk reduction benefits for people, the buildings, and hotels in Quintana Roo, particularly for low-return-periods storms (e.g., Hurricane Dean). The benefit of coral reefs to built capital, for example, varies from 100 to $60 \%$ as returns periods increase (Figure 7 and Table 2). This is because reefs increase their benefit 


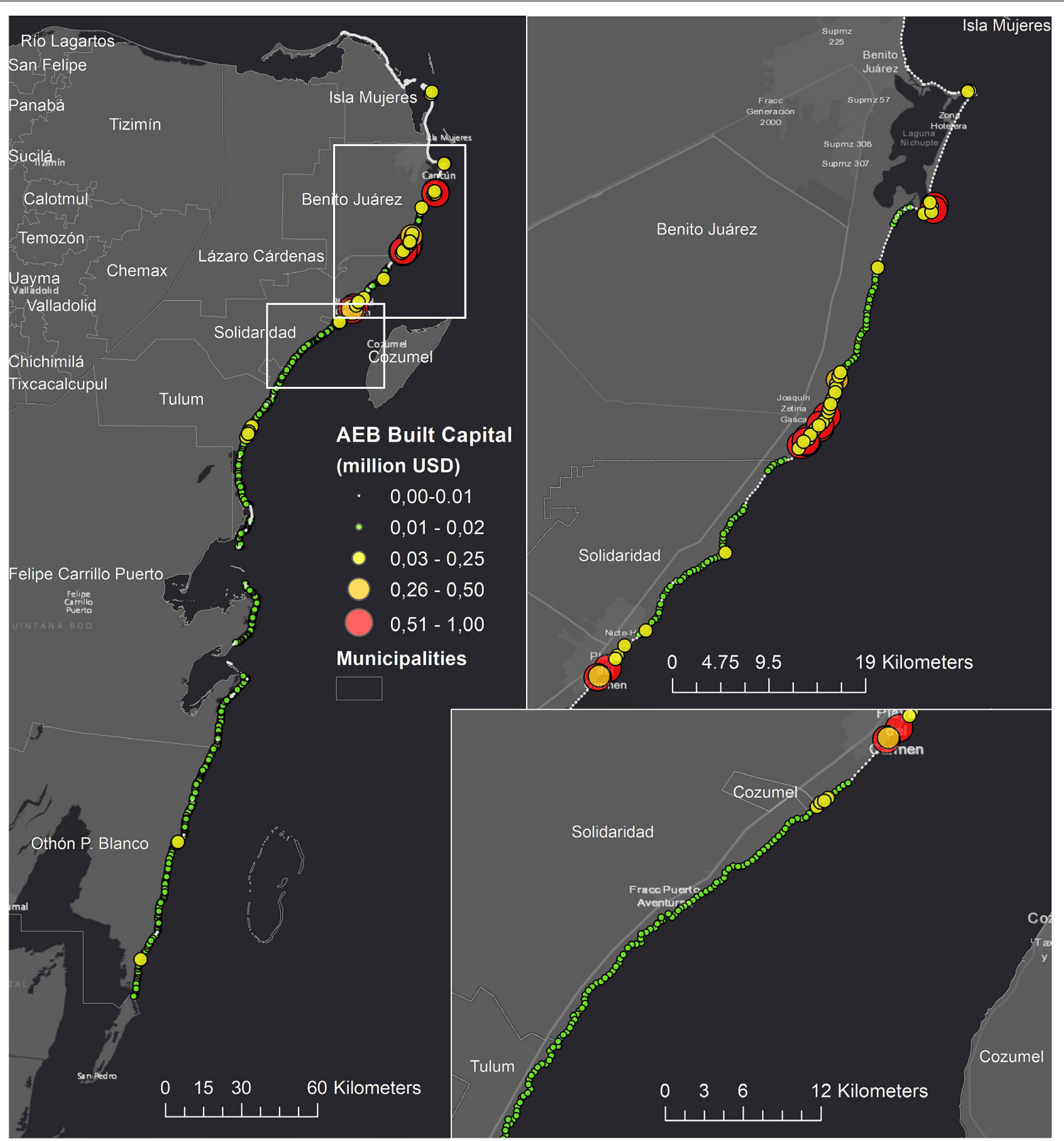

FIGURE 9 | Built capital protected from flooding per year. The points represent the annual expected benefit to built capital, in each coastal transect spaced 200-m along the coastline.

with larger waves, but they become less effective with higher water levels during the most intense and damaging events.

However, areas where reefs provide the most economic valuable protection do not always coincide with areas where people are protected the most, in particular for hotels, which for their location receive the largest protection from reefs. The spatial differences depend on the storm hazard (waves and sea levels); coral reefs presence, local water depth and friction; and the assets concentration on the coast. These spatial differences in flood prevention for the hotel infrastructure, the built capital, and people (Figures 10-12) differ, which has implications for coastal management and policy and may inform restoration strategies. These differences are relevant when determining where to maintain the natural protection offered by the reefs, for example through restoration, and who benefits most.

Explicit valuations of their protection services are particularly critical for coral reefs. As compared to other coastal ecosystems, quantifying their role in flood reduction require numerical models able to resolve complex processes at sufficient resolution (e.g., Quataert et al., 2015; Harris et al., 2018). Because reefs 


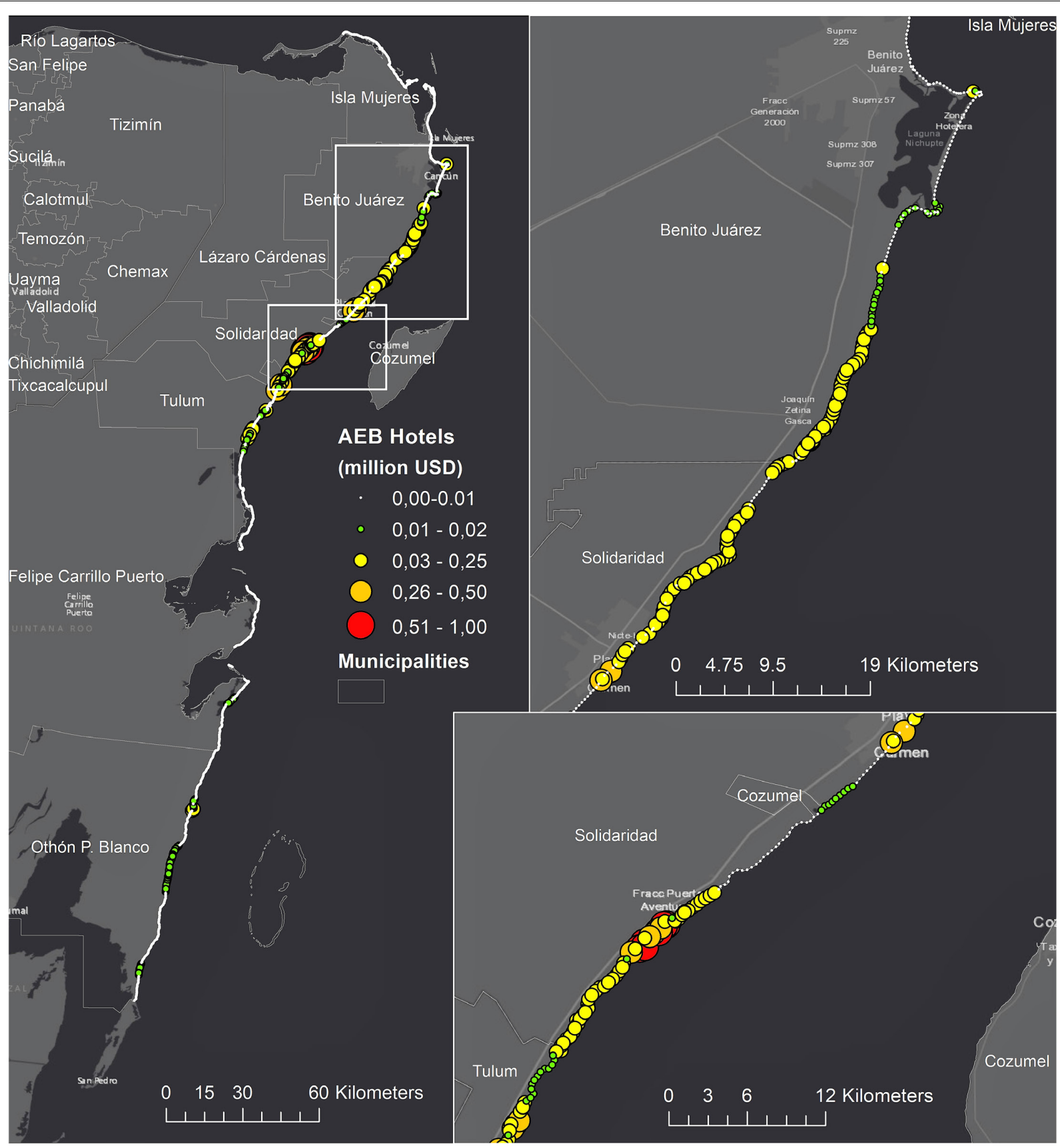

FIGURE 10 | Hotel capital protected from flooding per year. The points represent the annual expected benefit to hotels, in each coastal transect spaced 200-m along the coastline.

are under water, it has also been more challenging to make the connection between coral reef degradation and coastal risk increase than for other defenses or drivers of risk (e.g., Reguero et al., 2018a). For example, the loss of dunes, or intertidal habitats such as mangroves and marshes, is visibly apparent and hence communities recognize connections between habitat loss and flood damage. This has started to allow large-scale restoration practices and national policies. This study shows that spatial quantitative risk assessments are nowadays possible so reefs can be considered and maintained as a natural infrastructure for their services to communities and property.

Dunes also provide critical coastal protection in Quintana Roo. Topo-bathymetric data and the numerical modeling performed for the case of the coast of Quintana Roo, shows that, in general, when beaches have less protection from coral reefs, the dunes are higher and they are composed of coarser sand (Ruiz de Alegria-Arzaburu et al., 2013; Martínez et al., 2014). However, behind reefs, dunes are lower, and the sediment is finer 


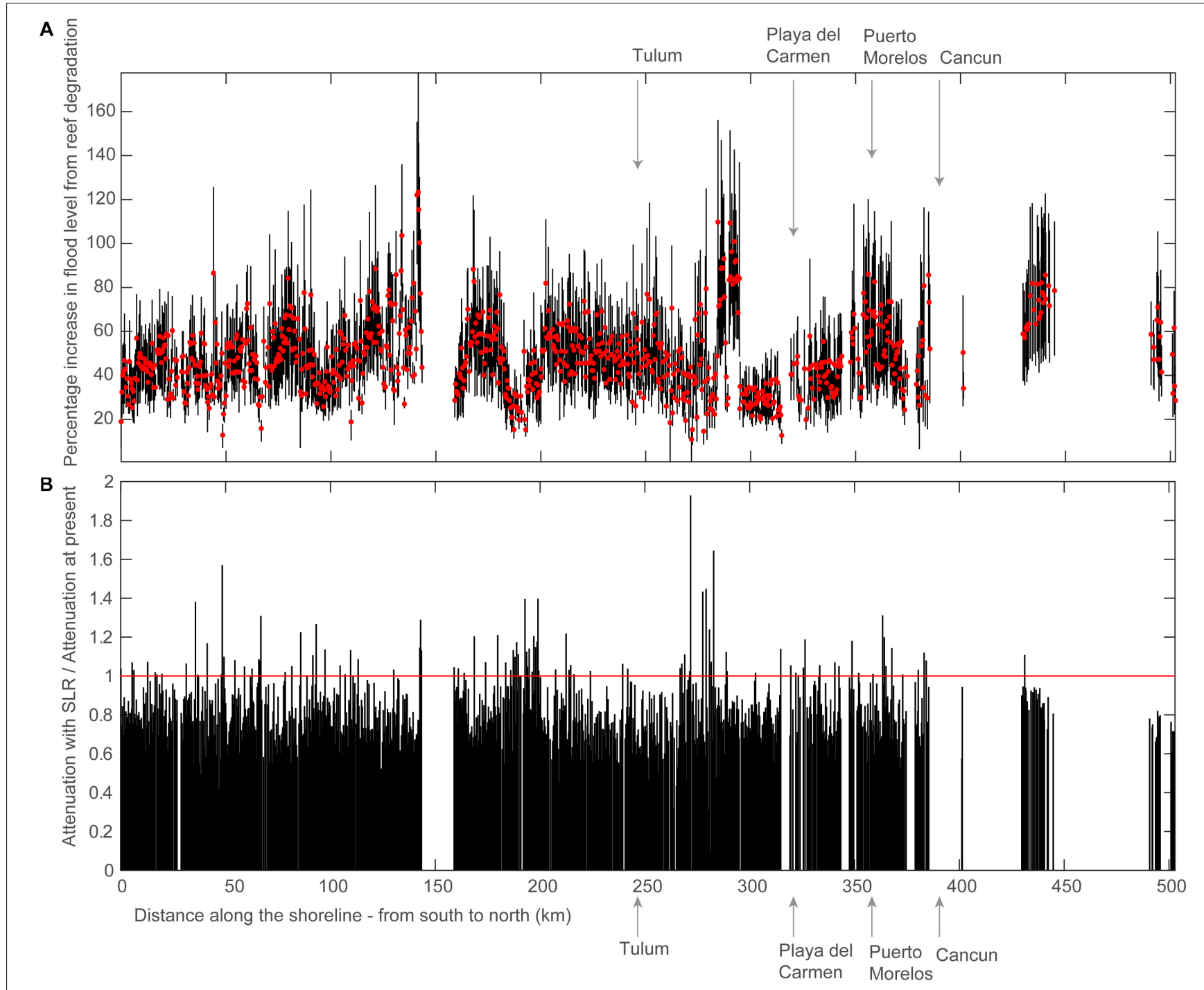

FIGURE 11 | Alongshore distribution in flood protection provided by coral reefs in Quintana Roo. (a) Flood reduction provided by the Mesoamerican Reef. The lines represent the range between the 25 and $75 \%$ percentiles of flood levels for each coastal transect. The red dots represent the mean value of flood reduction provided by the reef. (b) The ratio in flood reduction with sea-level rise (SRL) relative to present sea level. The local SLR was obtained from the mean value of the Representative Concentration Pathway 4.5 by the end of the $21^{\text {st }}$ century. The gaps represent no reef sections.

(Ruíz Cavazos et al., 2010). In sections without reefs in Puerto Morelos, longshore sediment transport is more intense and hence maintaining the beach width requires more input of sand (James et al., 2019). This behavior has important implications for coastal management: if coral reef degradation reduces the effect of reefs in the surf zone (e.g., dissipation of wave energy), the sediment transport will intensify, and beaches will require more sand to be maintained and even larger volumes of sediment to build dunes to reduce risk.

The comparison of the risk reduction from dunes and coral reefs reveals also important takeaways. This is the first time a study assesses and compares these natural infrastructures in terms of their contribution to coastal damage prevention. Although the analysis for dunes can be considered less rigorous than for reefs, given limitations on data and the simplified assumptions on their protective mechanisms (e.g., no consideration of important factors such as vegetation effect and erosion of beach and dunes), the comparison provides interesting insights into the complementary of these natural defenses. First, we identified the protection dunes offer larger protection than reefs for storms with higher probabilities. However, in sections with reefs, the annual risk reduction benefit of reefs largely exceeds those from dunes. This is explained by the effect of reefs on reducing flooding but also changes in dune heights in sections with reefs. Granulometric analyses in the region have shown that dunes behind reefs tend to be lower and sediment finer because the reef protection reduces surf zone dynamics and the movement of sediment that can be mobilized by the wind to grow dunes (Ruíz Cavazos et al., 2010). These results point out that both features are part of a whole 


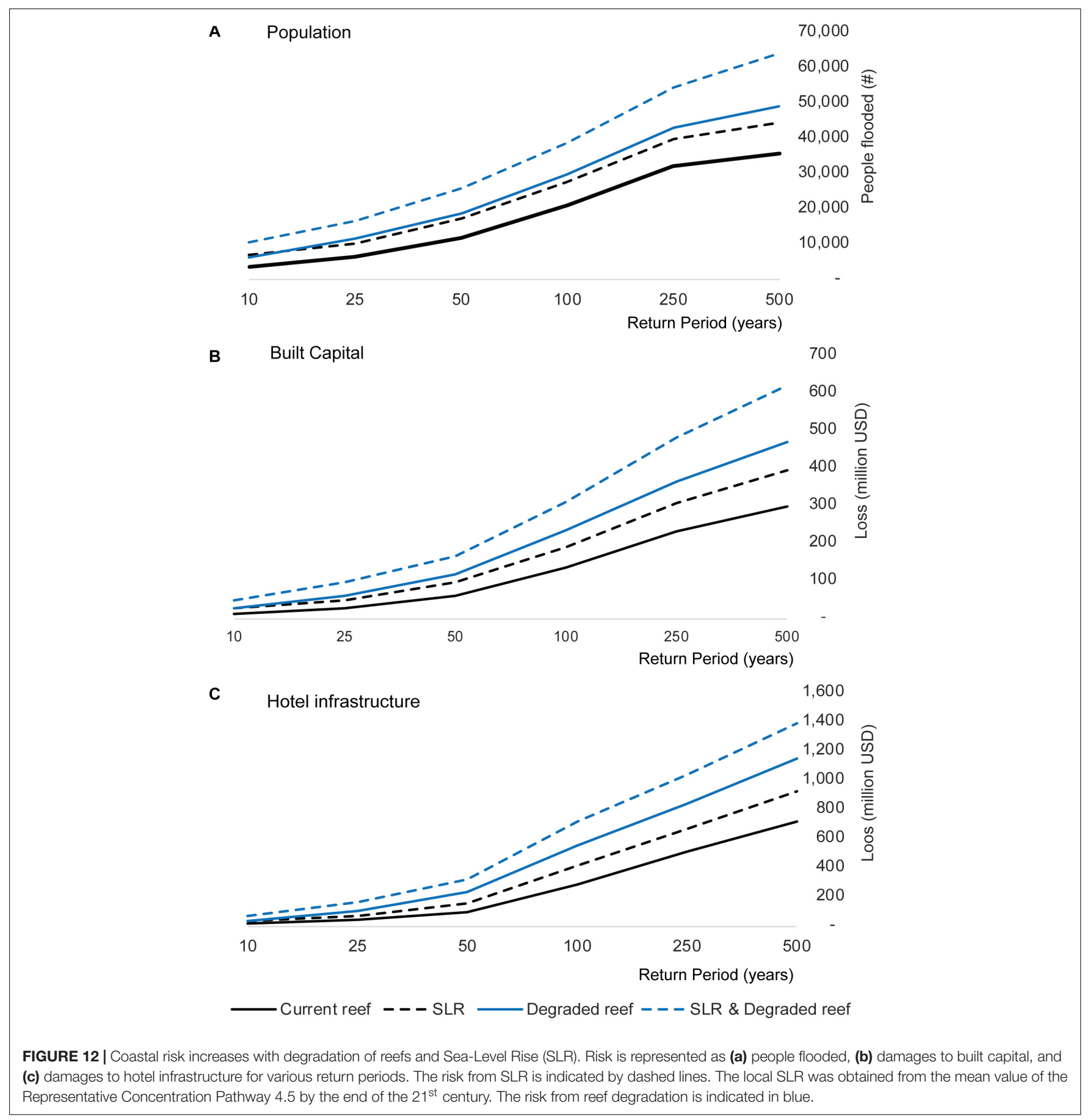

interconnected system and their location and properties are linked to each other.

This analysis also shows that these increases in coastal risk could be coupled with the significant impacts of a SLR and lead to compounding effects later in the century. We find that SLR increases notably the annual risk because it will produce greater impacts from storms. Furthermore, here we considered conservative estimates of SLR of $\sim 0.5 \mathrm{~m}$, although the projected values by the end of the century could reach $1 \mathrm{~m}$ of SLR (Church et al., 2013). Furthermore, we demonstrated that in coral reef environments, the contribution of reef degradation to coastal risk can exceed the contribution of these increases due to SLR. However, adaptation strategies still put the main focus on SLR adaptation while losing this natural infrastructure can be as damaging or more. The effect of reef degradation on coastal risk could also be more aggravated considering recent research that shows increasing power in the ocean waves associated to global warming (Reguero et al., 2019), which could both affect 
reef integrity but also enhance flooding. Therefore, the protective service of coral reefs becomes even more valuable with the rising threats of climate change.

These estimates also make a compelling case for presentday investments in coral reef management and conservation. We found benefits at certain sections of over 0.5 million USD per year in direct loss prevention. For reef sections of $200 \mathrm{~m}$, this represents 2,500 USD per alongshore linear meter of reef. The median cost per meter of reef restoration has been estimated in 1,290 USD per meter from a global review of projects (Ferrario et al., 2014). This means that this natural infrastructure, if well-maintained, provides on an annual basis a risk reduction that is equally or more valuable than the cost of restoring the reef to maintain this protection. Furthermore, a constructed pilot case in Grenada of a hybrid restoration project that included the construction of artificial submerged structures cost $\sim 3,300$ USD per alongshore linear meter (Reguero et al., 2018a). For this type of interventions, the annual benefits of reefs will also balance the costs over a 2-year period. In the MAR section of Quintana Roo, these results and approach can also help identify priority sites for conservation and restoration for coastal protection, either as 'stand-alone' solutions, or part of hybrid approaches that combine natural defenses, like coral reef restoration and dune rehabilitation, with built infrastructure.

Although the risk model was calibrated to represent the losses from historical storms, the results are affected by different uncertainty factors that are worth highlighting and could be improved with better data and modeling. The main factors for uncertainty include: offshore bathymetry data and parametric models for waves and surge definition; limited data on beach and dune topography and vegetation; a $90 \mathrm{~m}$ elevation model; lack of consideration of relevant process in dunes such as erosion by storms or wave runup attenuation by vegetation; simplified approach for flooding; asset distribution and economic value; and specific vulnerability curves for the buildings in the region. However, the analysis can also be considered conservative in the degree and the effects of reef degradation. Our scenarios do not assume that reefs will disappear altogether under a business-as-usual global climate emission scenario. The without reefs scenario assumes modest effects of degradation of $1 \mathrm{~m}$ change in reef profile (reef coral living layer and reef substrate), although similar flattening of coral reefs has been observed globally and could be accelerated by other threats in the MAR (Yates et al., 2017). Furthermore, this study did not analyze the effect of the reef on coastal erosion prevention, but this is likely to be a major benefit, particularly for the tourism sector. Research indicates that reefs can deter shoreline erosion through wave attenuation, energy dissipation and shifting, and sediment transport control (Reguero et al., 2018a).

Reefs provide a substantial first line of defense from coastal hazards and should be better managed for this benefit. Risk financing and insurance are critical in absorbing financial losses in the wake of disasters and natural catastrophes, and therefore, significant opportunities for restoration may lie in risk financing associated to the reefs' risk reduction service. Furthermore, in the wake of several destructive hurricanes in 2017, there is a growing need for policies that encourage the conservation and restoration of habitats that provide coastal protection, in the places where their degradation could represent significant increases in coastal risk to coastal communities and economies. Valuations of the protection services from coastal habitats in risk metrics as shown in this study could inform decisions to meet multiple objectives in risk reduction and environmental management.

Indeed, based on the MAR's risk reduction service in Mexico, the government and private industry are taking action to protect and provide innovative finance for coral reefs to mitigate coastal hazards and support tourism. In Quintana Roo, the government, hotel owners, The Nature Conservancy, and the local science community are piloting a pioneering strategy to confront these threats based on the socioeconomic benefits the coral reefs provide. This partnership has established a Coastal Zone Management Trust that can fund ongoing maintenance of coral reefs and beaches and purchase insurance to ensure these vital ecosystems are restored after extreme storms. This mechanism will provide financial protection to maintain the flood risk prevention reefs provide to people, built capital, and hotels in Quintana Roo. However, there is an opportunity to advance such innovations elsewhere too, through investment in risk financing for climate resilience (which could also include other ecosystem services). There is a large and growing pool of funding for natural infrastructure for risk reduction (Colgan et al., 2017), including innovative mechanisms for coral reefs (ICRI, 2018). New technologies and data can also inform these mechanisms and help monitor changes in the coastal landscape. However, only through riskbased valuations can coral reefs be incorporated in innovative risk finance to build the resilience of ecosystems and the economies they support.

\section{DATA AVAILABILITY}

All datasets generated for this study are included in the manuscript and/or the Supplementary Files.

\section{AUTHOR CONTRIBUTIONS}

$\mathrm{BR}, \mathrm{IL}$, and $\mathrm{MB}$ conceived and designed the analysis. BR and PD-S developed the methodology for economic exposure. AT and $\mathrm{ME}$ performed the exposure and geospatial analysis. BR and CS developed the reef modeling framework and simulations. $\mathrm{BR}, \mathrm{FS}, \mathrm{RS}$, and $\mathrm{MB}$ discussed the results and contributed to the final manuscript discussion. BR wrote the manuscript. All authors provided critical feedback and helped shape the research, analysis and manuscript.

\section{FUNDING}

Funding for this work was provided by The Nature Conservancy and The Kingfisher Foundation. 


\section{ACKNOWLEDGMENTS}

We sincerely thank the different organizations that provided data and information that enable this analysis, and the different donors and funding sources that supported this work. We especially thank different agencies from the Government of Mexico that provided crucial data for the analysis: 'Comisión Nacional para el Conocimiento y Uso de la Biodiversidad' (CONABIO), 'Instituto Nacional de Estadística y Geografía' (INEGI),

\section{REFERENCES}

Alvarez-Filip, L., Dulvy, N. K., Gill, J. A., Côté, I. M., and Watkinson, A. R. (2009). Flattening of Caribbean coral reefs: region-wide declines in architectural complexity. Proc. Biol. Sci. 276, 3019-3025. doi: 10.1098/rspb.2009.0339

Aznar-Siguan, G., and Bresch, D. N. (2019). CLIMADA - a global weather and climate risk assessment platform. Geosci. Model Dev. Discuss. 2019, 1-18. doi: 10.5194/gmd-2018-338

Baldock, T. E., Golshani, A., Callaghan, D. P., Saunders, M. I., and Mumby, P. J. (2014). Impact of sea-level rise and coral mortality on the wave dynamics and wave forces on barrier reefs. Mar. Pollut. Bull. 83, 155-164. doi: 10.1016/j. marpolbul.2014.03.058

Barbier, E. B. (2015). Valuing the storm protection service of estuarine and coastal ecosystems. Ecosyst. Serv. 11, 32-38. doi: 10.1016/j.ecoser.2014.06.010

Beck, M. W., Losada, I. J., Menéndez, P., Reguero, B. G., Díaz-Simal, P., and Fernández, F. (2018). The global flood protection savings provided by coral reefs. Nat. Commun. 9:2186. doi: 10.1038/s41467-018-04568-z

Bellwood, D. R., Hughes, T. P., Folke, C., and Nystrom, M. (2004). Confronting the coral reef crisis. Nature 429, 827-833. doi: 10.1038/nature02691

Bretschneider, C. L. (1990). “Tropical cyclones," in Handbook of Coastal \& Ocean Engineering, eds J. B. Herbich and C. L. Bretschneider (Houston: Gulf Pub. Co.), 249-303.

Briggs, S., Kennel, C. F., and Victor, D. G. (2015). Planetary vital signs. Nat. Clim. Chang. 5:969. doi: 10.1038/nclimate2828

Camus, P., Mendez, F. J., and Medina, R. (2011a). A hybrid efficient method to downscale wave climate to coastal areas. Coast. Eng. 58, 851-862. doi: 10.1016/ j.coastaleng.2011.05.007

Camus, P., Mendez, F. J., Medina, R., and Cofiño, A. S. (2011b). Analysis of clustering and selection algorithms for the study of multivariate wave climate. Coast. Eng. 58, 453-462. doi: 10.1016/j.coastaleng.2011.02.003

Church, J. A., Clark, P. U., Cazenave, A., Gregory, J. M., Jevrejeva, S., Levermann, A., et al. (2013). "Sea level change," in The Physical Science Basis: Contribution of Working Group I to the Fifth Assessment Report of the Intergovernmental Panel on Climate Change, eds T. F. Stocker, D. Qin, G.-K. Plattner, and M. Tignor (Cambridge: Cambridge University Press).

Colgan, C. S., Beck, M. W., and Narayan, S. (2017). Financing Natural Infrastructure for Coastal Flood Damage Reduction. London: Lloyd's Tercentenary Research Foundation.

Dean, R. G., and Dalrymple, R. A. (1991). Water Wave Mechanics for Engineers and Scientists. Singapore: World Scientific.

Escalante-Mancera, E., Silva, R., Mendoza, E., Mariño-Tapia, I., and Ruiz-Renteria, F. (2009). Análisis de la variación del nivel del mar y de las corrientes inducidas por el huracán wilma en puerto morelos, quintana roo. Rev. Ing. Hidráulica en México 24, 111-126.

Escudero-Castillo, M., Felix-Delgado, A., Silva, R., Mariño-Tapia, I., and Mendoza, E. (2018). Beach erosion and loss of protection environmental services in Cancun. Mexico. Ocean Coast. Manag. 156, 183-197. doi: 10.1016/j.ocecoaman. 2017.06.015

Escudero-Castillo, M., Mendoza, E., Silva, R., and Villatoro, M. (2014a). Comparative risk assessment at isla del carmen and cancun, mexico. Coast. Eng. Proc. 1:10. doi: 10.9753/icce.v34.management.10

Escudero-Castillo, M., Silva, R., and Mendoza, E. (2014b). Beach erosion driven by natural and human activity at isla del carmen barrier island, mexico. J. Coast. Res. 62-74. doi: 10.2112/SI71-008.1 and 'Centro Nacional de Prevención de Desastres' (CENAPRED). We also thank Sean Vitousek for the useful comments provided.

\section{SUPPLEMENTARY MATERIAL}

The Supplementary Material for this article can be found online at: https://www.frontiersin.org/articles/10.3389/feart. 2019.00125/full\#supplementary-material

Farr, T. G., Rosen, P. A., Caro, E., Crippen, R., Duren, R., Hensley, S., et al. (2007). The shuttle radar topography mission. Rev. Geophys. 45:33. doi: 10. 1029/2005RG000183

Feagin, R. A., Furman, M., Salgado, K., Martinez, M. L., Innocenti, R. A., Eubanks, K., et al. (2019). The role of beach and sand dune vegetation in mediating wave run up erosion. Estuar. Coast. Shelf Sci. 219, 97-106. doi: 10.1016/j.ecss.2019. 01.018

Ferrario, F., Beck, M. W., Storlazzi, C. D., Micheli, F., Shepard, C. C., and Airoldi, L. (2014). The effectiveness of coral reefs for coastal hazard risk reduction and adaptation. Nat. Commun. 5:3794. doi: 10.1038/ncomms4794

Graham, N. A. J., Jennings, S., MacNeil, M. A., Mouillot, D., and Wilson, S. K. (2015). Predicting climate-driven regime shifts versus rebound potential in coral reefs. Nature 518, 94-97. doi: 10.1038/nature14140

Guanche, Y., Camus, P., Guanche, R., Mendez, F. J., and Medina, R. (2013). A simplified method to downscale wave dynamics on vertical breakwaters. Coast. Eng. 71, 68-77. doi: 10.1016/j.coastaleng.2012.08.001

Guannel, G., Arkema, K., Ruggiero, P., and Verutes, G. (2016). The power of three: coral reefs, seagrasses and mangroves protect coastal regions and increase their resilience. PLoS One 11:e0158094. doi: 10.1371/journal.pone. 0158094

Hallegatte, S., Green, C., Nicholls, R. J., and Corfee-Morlot, J. (2013). Future flood losses in major coastal cities. Nat. Clim. Chang. 3, 802-806. doi: 10.1038/ nclimate 1979

Harris, D. L., Rovere, A., Casella, E., Power, H., Canavesio, R., Collin, A., et al. (2018). Coral reef structural complexity provides important coastal protection from waves under rising sea levels. Sci. Adv. 4:eaao4350. doi: 10.1126/sciadv. aao4350

ICRI (2018). Innovations for Coral Finance. Tokyo: ICRI.

INEGI (2015). Principales Resultados de la Encuesta Intercensal 2015. Mexico: Instituto nacional de estadistica y geografia.

James, R. K., Silva, R., van Tussenbroek, B. I., Escudero-Castillo, M., Mariño-Tapia, I., Dijkstra, H. A., et al. (2019). Maintaining tropical beaches with seagrass and algae: a promising alternative to engineering solutions. BioScience 69, 136-142. doi: 10.1093/biosci/biy154

Lloyd, C. T., Sorichetta, A., and Tatem, A. J. (2017). High resolution global gridded data for use in population studies. Sci. Data 4:170001. doi: 10.1038/sdata.2017.1

Lowe, R. J., Falter, J. L., Bandet, M. D., Pawlak, G., Atkinson, M. J., Monismith, S. G., et al. (2005). Spectral wave dissipation over a barrier reef. J. Geophys. Res. Ocean 110, 5-20. doi: 10.1029/2004JC002711

Martínez, M. L., Moreno-Casasola, P., Espejel, I., Orocio Jimenez, O. A., and Infante Mata, N. (2014). Diagnóstico General de las Dunas Costeras de México. México, D.F: Comisión Nacional Forestal.

Mcfield, M., Kramer, P., Alvarez-Filip, L., Drysdale, I., Marisol, R.-F., Giro, A., et al. (2018). 2018 Mesoamerican Reef Report Card. doi: 10.13140/RG.2.2.19679. 36005

Mechler, R., and Schinko, T. (2016). Identifying the policy space for climate loss and damage. Science 354, 290-292. doi: 10.1126/science. aag2514

Mendoza, E., Silva, R., Enriquez-Ortiz, C., Mariño-Tapia, I., and Felix, A. (2015). "Analysis of the hazards and vulnerability of the cancun beach system," in Extreme Events: Observations, Modeling, and Economics, Chapter: Analysis of the Hazards and Vulnerability of the Cancun Beach System, eds M. Chavez, M. Ghil, and J. Urrutia-Fucugauchi (Hoboken: John Wiley \& Sons, Inc), doi: 10.1002/9781119157052.ch10 
Menéndez, P., Losada, I. J., Beck, M. W., Torres-Ortega, S., Espejo, A., Narayan, S., et al. (2018). Valuing the protection services of mangroves at national scale: the Philippines. Ecosyst. Serv. 34, 24-36. doi: 10.1016/j.ecoser.2018.09.005

Meza-Padilla, R., Appendini, C., and Pedrozo-Acuña, A. (2015). Hurricaneinduced waves and storm surge modeling for the Mexican coast. Ocean Dyn. 65, 1199-1211. doi: 10.1007/s10236-015-0861-867

Monismith, S. G. (2007). Hydrodynamics of coral reefs. Annu. Rev. Fluid Mech. 39, 37-55. doi: 10.1146/annurev.fluid.38.050304.092125

Narayan, S., Beck, M. W., Wilson, P., Thomas, C. J., Guerrero, A., Shepard, C. C., et al. (2017). The value of coastal wetlands for flood damage reduction in the Northeastern USA. Sci. Rep. 7:9463. doi: 10.1038/s41598-017-09269-z

Neumann, B., Vafeidis, A. T., Zimmermann, J., and Nicholls, R. J. (2015). Future coastal population growth and exposure to sea-level rise and coastal flooding - a global assessment. PLoS One 10:e0118571. doi: 10.1371/journal.pone.0118571

National Oceanic, and Atmospheric Administration [NOAA] (2006). ETOPO2v2 Global Gridded 2-minute Database. Silver Spring, MD: NOAA.

Perry, C. T., Alvarez-Filip, L., Graham, N. A. J., Mumby, P. J., Wilson, S. K., Kench, P. S., et al. (2018). Loss of coral reef growth capacity to track future increases in sea level. Nature 558, 396-400. doi: 10.1038/s41586-018-0194-z

Posada, G., Silva, R., and de Brye, S. (2008). Three dimensional hydrodynamic model with multiquadtree meshes. Am. J. Environ. Sci. 4, 245-258. doi: 10.3844/ ajessp.2008.245.258

Quataert, E., Storlazzi, C., van Rooijen, A., Cheriton, O., and van Dongeren, A. (2015). The influence of coral reefs and climate change on wave-driven flooding of tropical coastlines. Geophys. Res. Lett. 42, 6407-6415. doi: 10.1002/ 2015GL064861

Rabus, B., Eineder, M., Roth, A., and Bamler, R. (2003). The shuttle radar topography mission-a new class of digital elevation models acquired by spaceborne radar. ISPRS J. Photogramm. Remote Sens. 57, 241-262. doi: 10. 1016/S0924-2716(02)00124-127

Reguero, B. G., Beck, M. W., Agostini, V. N., Kramer, P., and Hancock, B. (2018a). Coral reefs for coastal protection: a new methodological approach and engineering case study in Grenada. J. Environ. Manage. 210, 146-161. doi: 10.1016/j.jenvman.2018.01.024

Reguero, B. G., Beck, M. W., Bresch, D. N., Calil, J., and Meliane, I. (2018b). Comparing the cost effectiveness of nature-based and coastal adaptation: a case study from the gulf coast of the United States. PLoS One 13:e192132. doi: 10.1371/journal.pone.0192132

Reguero, B. G., Losada, I. J., Díaz-Simal, P., Méndez, F. J., and Beck, M. W. (2015). Effects of climate change on exposure to coastal flooding in latin america and the caribbean. PLoS One 10:e0133409. doi: 10.1371/journal.pone. 0133409

Reguero, B. G., Losada, I. J., and Méndez, F. J. (2019). A recent increase in global wave power as a consequence of oceanic warming. Nat. Commun. 10:205. doi: 10.1038/s41467-018-08066-8060

Resio, D. T., and Irish, J. L. (2015). Tropical cyclone storm surge risk. Curr. Clim. Chang. Reports 1, 74-84. doi: 10.1007/s40641-015-0011-19

Ruíz Cavazos, D., Ruíz Martínez, G., Mendoza, E., and Silva, R. (2010). Distribución del Sedimento en las Costas de Yucatán y Quintana Roo XXI Congreso Nacional de Hidráulica. Guadalajara: AMH.

Ruiz de Alegria-Arzaburu, A., Mariño-Tapia, I., Enriquez, C., Silva, R., and González-Leija, M. (2013). The role of fringing coral reefs on beach morphodynamics. Geomorphology 198, 69-83. doi: 10.1016/j.geomorph.2013. 05.013

Samonte-Tan, G. P. B., White, A. T., Tercero, M. A., Diviva, J., Tabara, E., and Caballes, C. (2007). Economic valuation of coastal and marine resources: bohol marine triangle. Philippines. Coast. Manag. 35, 319-338. doi: 10.1080/ 08920750601169634
Scawthorn, C., Blais, N., Seligson, H., Tate, E., Mifflin, E., Thomas, W., et al. (2006a). HAZUS-MH flood loss estimation methodology. I: overview and flood hazard characterization. Nat. Hazards Rev. 7, 60-71. doi: 10.1061/(ASCE)1527698820067:2(60)

Scawthorn, C., Flores, P., Blais, N., Seligson, H., Tate, E., Chang, S., et al. (2006b). HAZUS-MH flood loss estimation methodology. II. damage and loss assessment. Nat. Hazards Rev. 7, 72-81. doi: 10.1061/(ASCE)1527698820067:2(72)

Silva, R., Mendoza, E., Escalante, E., Mariño, I., and Ruiz, F. (2009). Oleaje inducido por el huracán wilma en puerto morelos, quintana roo, méxico. Rev. Ing. Hidraúlica en México XXIV 24, 93-109.

Silva, R., Martínez, M. L., Hesp, P. A., Catalán, P., Osorio, A., Martell, R., et al. (2014). Present and future challenges of coastal erosion in latin America. J. Coast. Res. 71, 1-16. doi: 10.2112/SI71-001.1

Storlazzi, C. D., Gingerich, S. B., van Dongeren, A., Cheriton, O. M., Swarzenski, P. W., Quataert, E., et al. (2018). Most atolls will be uninhabitable by the mid21 st century because of sea-level rise exacerbating wave-driven flooding. Sci. Adv. 4:eaa9741. doi: 10.1126/sciadv.aap9741

Storlazzi, C., Reguero, B., Lowe, E., Shope, J., Gibbs, A., Beck, M., et al. (2017). Rigorously valuing the role of coral reefs in coastal protection: an example from Maui. Hawaii, USA. Coast. Dyn. 2017:035.

UNFCCC (2013). Warsaw International Mechanism for Loss and Damage. Bonn: UNFCCC.

UNFCCC (2015). Paris Agreement. Bonn: UNFCCC

UNISDR (2015). 2015 Global Assessment Report on Disaster Risk Reduction. Geneva: UNISDR

Valdez, G. D. (2010). Análisis del Peligro por Marea de Tormenta en el Golfo de México. Tesis Maestría (Maestría en Ingeniería Civil)-UNAM. México: Instituto de Ingeniería.

van Dongeren, A., Lowe, R., Pomeroy, A., Trang, D. M., Roelvink, D., Symonds, G., et al. (2013). Numerical modeling of low-frequency wave dynamics over a fringing coral reef. Coast. Eng. 73, 178-190. doi: 10.1016/j.coastaleng.2012.11.004

Wong, P. P., Losada, I. J., Gattuso, J.-P., Hinkel, J., Khattabi, A., McInnes, K. L., et al. (2014). "Coastal systems and low-lying areas," in Climate Change 2014: Impacts, Adaptation, and Vulnerability. Part A:Global and Sectoral Aspects. Contribution of Working Group II to the Fifth Assessment Report of theIntergovernmental Panel on Climate Change, eds V. R. Barros, D. J. Dokken, K. J. Mach, M. D. Mastrandrea, T. E. Bilir, M. Chatterjee, (Cambridge: Cambridge University Press), 361-409.

Yates, K. K., Zawada, D. G., Smiley, N. A., and Tiling-Range, G. (2017). Divergence of seafloor elevation and sea level rise in coral reef ecosystems. Biogeosciences 14, 1739-1772. doi: 10.5194/bg-14-1739-2017

Young, I. (1988). Parametric hurricane wave prediction model. J. Waterw. Port Coastal Ocean Eng. 114, 637-652. doi: 10.1061/(ASCE)0733-950X1988114: $5(637)$

Conflict of Interest Statement: The authors declare that the research was conducted in the absence of any commercial or financial relationships that could be construed as a potential conflict of interest.

Copyright (C) 2019 Reguero, Secaira, Toimil, Escudero, Díaz-Simal, Beck, Silva, Storlazzi and Losada. This is an open-access article distributed under the terms of the Creative Commons Attribution License (CC BY). The use, distribution or reproduction in other forums is permitted, provided the original author(s) and the copyright owner(s) are credited and that the original publication in this journal is cited, in accordance with accepted academic practice. No use, distribution or reproduction is permitted which does not comply with these terms. 